\title{
Deep-Buried Triassic Oil-Source Correlation in the Central Junggar Basin, NW China
}

\author{
Ming Wu, ${ }^{1,2}$ Jun Jin, ${ }^{3}$ Wanyun $M a,{ }^{3}$ Baoli Xiang, ${ }^{3}$ Ni Zhou, ${ }^{3}$ Jiangling Ren, ${ }^{3}$ and Jian Cao \\ ${ }^{1}$ State Key Laboratory for Mineral Deposits Research, Department of Earth Sciences, Nanjing University, Nanjing, \\ Jiangsu 210023, China \\ ${ }^{2}$ Department of Earth and Planetary Sciences, Washington University, St. Louis, MO 63130, USA \\ ${ }^{3}$ Research Institute of Experiment and Testing, PetroChina Xinjiang Oilfield Company, Karamay, Xinjiang 843000, China
}

Correspondence should be addressed to Jian Cao; jcao@nju.edu.cn

Received 26 February 2017; Accepted 4 May 2017; Published 11 June 2017

Academic Editor: Shuichang Zhang

Copyright (C) 2017 Ming Wu et al. This is an open access article distributed under the Creative Commons Attribution License, which permits unrestricted use, distribution, and reproduction in any medium, provided the original work is properly cited.

\begin{abstract}
Whether there is an effective deep-buried lacustrine Triassic petroleum system in the Junggar Basin, NW China, has been enigmatic and debated for a long time. Here we conduct an oil-source correlation to address this issue. Results show that the extracted bitumens from the Triassic mudstones in the central basin have distinctive stable carbon isotope and biomarker compositions compared to the Permian-sourced and Jurassic-sourced hydrocarbons, the other two recognized sources in the study area. These characteristics include $\delta^{13} \mathrm{C}$ value of $-30.46 \sim-26.30 \%$ o, $\beta$-carotane/maximum $n$-alkane of $0.22-0.41, \mathrm{Pr} / \mathrm{Ph}$ of $1.00-1.51, \mathrm{C}_{24}$ tetracyclic terpane/ $\mathrm{C}_{26}$ tricyclic terpane of 0.43-0.96, Ts/Tm of 0.34-0.64, gammacerane/ $\mathrm{C}_{30}$ hopane of 0.10-0.14, and regular steranes $\mathrm{C}_{27}>\mathrm{C}_{28}<\mathrm{C}_{29}$ with $\mathrm{C}_{29}$ sterane in dominance (40-50\%). These suggest that the Triassic mudstones in the study area host fresh lacustrine organic matters with high input of higher plants. The Triassic-reservoired crude oils and extracts can be divided into two types. Through oil-source correlation, we infer that both type A and type B oils are derived from mixed Permian and Triassic source rocks. Linear regression analysis shows that the contribution from Triassic mudstones to type A and B oils is $67 \%$ and $31 \%$, respectively. This implies that the deep-buried Triassic lacustrine mudstones in the Junggar Basin may have some oil-generation potential and thus might represent a new case of Triassic petroleum systems in China and deserves a more detailed and thorough study in future exploration and exploitation.
\end{abstract}

\section{Introduction}

The Triassic sediments have contributed to global petroleum reserves and production at approximately $2.0 \%[1,2]$. The major Triassic source rocks are deposited in marginal marine, marine shelf settings, or other shallow marine environments, such as the Lower-Middle Triassic Locker Shale in Northwest Australia, the Middle-Upper Triassic Carbonates in Arabian Platform, and the Middle-Upper Triassic Shublik-Otuk interval in Alaska [3]. In China, the major Triassic source rocks include both lacustrine mudstones deposited during flooding periods, such as the Upper Triassic Yanchang Formation in the Erdos Basin [4] and Huangshanjie Formation in the Tarim Basin [5], and marine limestone and argillaceous rocks such as the Upper Triassic Xiaochaka Formation in the Qiangtang Basin [6].
The Junggar Basin, located in northwestern China and being one of the most petroliferous basins in NW China, is typified by development of multiple source rocks, from old to young including Carboniferous, Permian, Jurassic, Cretaceous, and Paleogene [7-13]. In addition, Triassic has been proposed to be a candidate for source rock [14-16]. This understanding was obtained mainly based on two reasons. First, a flooding event in a lacustrine basin is commonly accompanied by development of high-quality hydrocarbon source rocks, which lay the foundation for formation of large oil and gas fields; notable examples include the Late Triassic to Early Jurassic lake system in the Jameson Land Basin, East Greenland $[17,18]$ and the Late Cretaceous lake system in the Songliao Basin, China $[19,20]$. In the Junggar Basin, the Triassic, particularly the Upper Triassic Baijiantan Formation $\left(\mathrm{T}_{3} b\right)$, has been proved to be deposited during a lacustrine 
flooding period [21-23] and shown to be an important set of regional caprock [24-26]. Thus, theoretically, Triassic formation in the Junggar Basin may be an important set of hydrocarbon source rocks. Second, for the Triassic the underlying Permian and overlying Jurassic have both been validated to be effective source rocks $[7,11,27-29]$. This implies that the Triassic has the maturity condition for hydrocarbon generation given that the Triassic is organic-rich.

Wu et al. [16] conducted a pilot study on the geochemical evaluation of the Triassic mudstones in the central Junggar Basin and concluded that the Triassic has hydrocarbon generation potential, with gas in dominance and some oil. This, in turn, implies that the established petroleum systems in the basin might need to be reevaluated. It seems that there are no large amounts of generated gas [30] because the maturity of the Triassic has not reached the gas-generation window [16]. Thus, the critical issue in the study of whether the Triassic can be effective hydrocarbon source rocks in the Junggar Basin is oil-generation ability and associated resource prospects.

However, this issue has not received large research attention because petroleum resources have been believed to be sufficient in the basin. Only a few preliminary studies have noted that there are possible Triassic oil-source rocks in the basin. Chen et al. [14] analyzed the geochemical features of Carboniferous, Permian, Triassic, and Jurassic source rocks as well as the crude oils in the eastern Junggar Basin. The geochemical assessment of the genetic potential of the multiple source rocks showed that the Triassic source rocks should have generated certain amounts of oils. Late on, Chen et al. [15] quantified the Triassic contribution to the mixed oils at $15 \%$ based on artificial mixing experiments and mixing calculations by using whole-oil carbon isotope ratios and absolute concentrations of biomarkers.

Along with the increasing exploration level in the basin, it becomes more and more important to know if there are additional source rock sequences in the basin. Thus, this paper aims to clarify the oil-generation potential of the Triassic mudstones in the basin by using an oil-source correlation study. We focused on the central Junggar Basin because it is the typical area reported to develop Triassic source rocks [16].

\section{Geologic Setting}

The Junggar Basin of NW China, which covers an area of ca. $1.3 \times 10^{5} \mathrm{~km}^{2}$, is located in the northern Xinjiang Uygur Autonomous Region and is a superimposed petroliferous basin (Figure 1(a)). This triangular basin is bounded by mountains from four sides, including the Qinggelidi-Kelameili Mountains to the east, the Zhayier Mountains to the west, the Tianshan Mountains (i.e., Yilinheibiergen and Bogeda Mountains) to the south, and the Altai Mountains (i.e., Delun Mountains) to the north (Figure 1(a)). The Junggar Basin comprises Paleozoic, Mesozoic, and Cenozoic strata [32, 33] (Figure 1(a)) deposited on a pre-Carboniferous folding and crystallized two-story basement $[34,35]$. The location of the studied central Junggar Basin is indicated in Figure 1(b).

The Junggar Basin was subject to a continuous subsidence during the Triassic and the crust mainly experienced vertical rising and sinking [21-23]. Because of basin subsidence and expansion, especially the deposition of the Upper Triassic, the fault depression and fault-uplift belts throughout the basin formed during the Permian rifting [36] were gradually uniformized, providing favorable conditions for development of hydrocarbon source rocks [37].

The Triassic formation in the central Junggar Basin from bottom to up consists of the Lower Baikouquan Formation $\left(\mathrm{T}_{1} b\right)$, the Middle Karamay Formation $\left(\mathrm{T}_{2} k\right)$, and the Upper Baijiantan Formation $\left(\mathrm{T}_{3} b\right)$. The sedimentary facies evolved from alluvial fan plains, to shore-shallow lakes, to braidedriver deltaic fronts, to shore-shallow lakes, to swamps, to shallow lakes, and to deep lakes (Figure 2) [22]. $\mathrm{T}_{1} b$ consists of brown/gray siltstone, fine-grained sandstone, and gray/ brown mudstones. $\mathrm{T}_{2} k$ presents as gray and dark gray mudstone, silty mudstone, and carbonaceous mudstone, interbedded with some laminated coal seams. $\mathrm{T}_{3} b$ is lithologically dominated by gray and dark gray mudstones, interbedded with thin layers of siltstones and fine-grained to mediumgrained sandstones.

\section{Samples and Methods}

Samples used in this oil-source correlation study include mudstone source rocks, reservoir oils, and sandstone extracts. The Triassic mudstones over the central Junggar Basin have different organic matter types and maturities [16]. Based on the dataset reported by Wu et al. [16], eight mudstone samples with hydrogen index $(\mathrm{HI})>100 \mathrm{mg} / \mathrm{g}$ TOC from well SM 1 are collected to represent Triassic possible hydrocarbon source rocks. For oil-source correlation, we also collect three Triassic-reservoired crude oils and five oil-bearing sandstones (Tables 1 and 2).

Fresh mudstones were crushed into powders which were used for geochemical analysis. For TOC analysis, sample splits $(200 \mathrm{mg})$ were treated with $10 \%$ by volume $\mathrm{HCl}$ at $60^{\circ} \mathrm{C}$ to remove any carbonate, before the samples were washed with distilled water to remove the $\mathrm{HCl}$. The samples were then dried overnight at $50^{\circ} \mathrm{C}$ before analysis with a LECO SC144DR Carbon-Sulfur Analyzer.

Rock-Eval pyrolysis was performed using 100-mg crushed mudstone samples and a Rock-Eval VI instrument. These samples were heated to $600^{\circ} \mathrm{C}$ in a helium atmosphere, thus generating values for four main parameters, including $S_{1}, S_{2}, S_{3}$, and Tmax, where $S_{1}$ is the amount of free hydrocarbon that can be volatilized from the rock sample (in $\mathrm{mg}$ $\mathrm{HC} / \mathrm{g}$ rock), $S_{2}$ is the amount of hydrocarbon produced by cracking of organic matter in the rock (mg HC/g rock), $S_{3}$ is the amount of $\mathrm{CO}_{2}$ produced during the analysis $(\mathrm{mg}$ $\mathrm{HC} / \mathrm{g}$ rock), and $\operatorname{Tmax}\left({ }^{\circ} \mathrm{C}\right)$ is the temperature at which the maximum $S_{2}$ yield is reached, which gives a rough estimate of thermal maturity.

Vitrinite reflectance $\left(R_{o}\right)$ measurements were performed using a Zeiss Axioskop $40 \mathrm{Pol}$ incident light microscope at a wavelength $(\lambda)$ of $546 \mathrm{~nm}$ with a $50 \mathrm{x} / 0.85$ oil objective. Yttrium aluminum garnet standard (GWB13401) with a reflectance of $0.588 \%$ was used for calibration during analysis, and at least 50 measurements were performed on each sample analyzed during the study. 


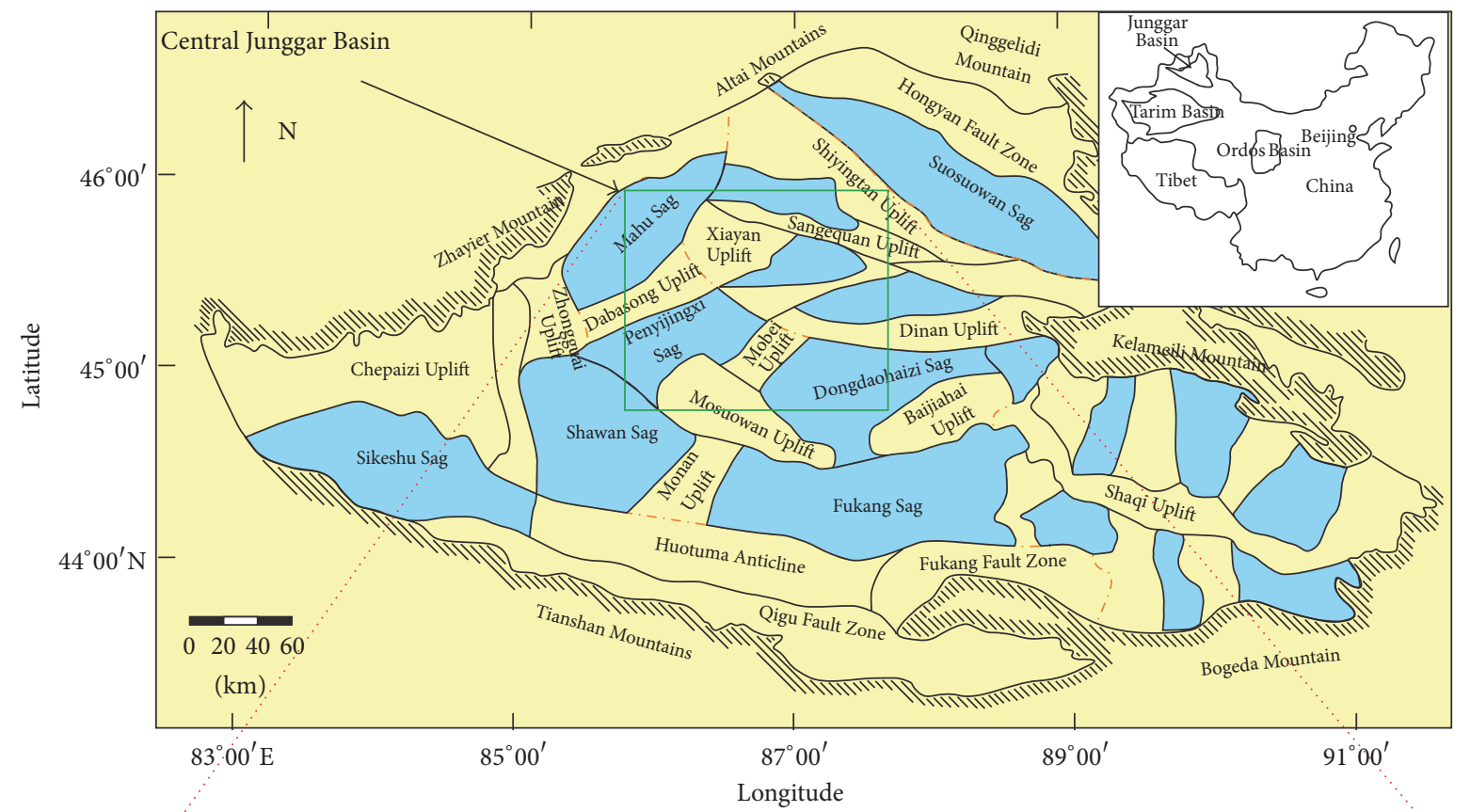

(a)

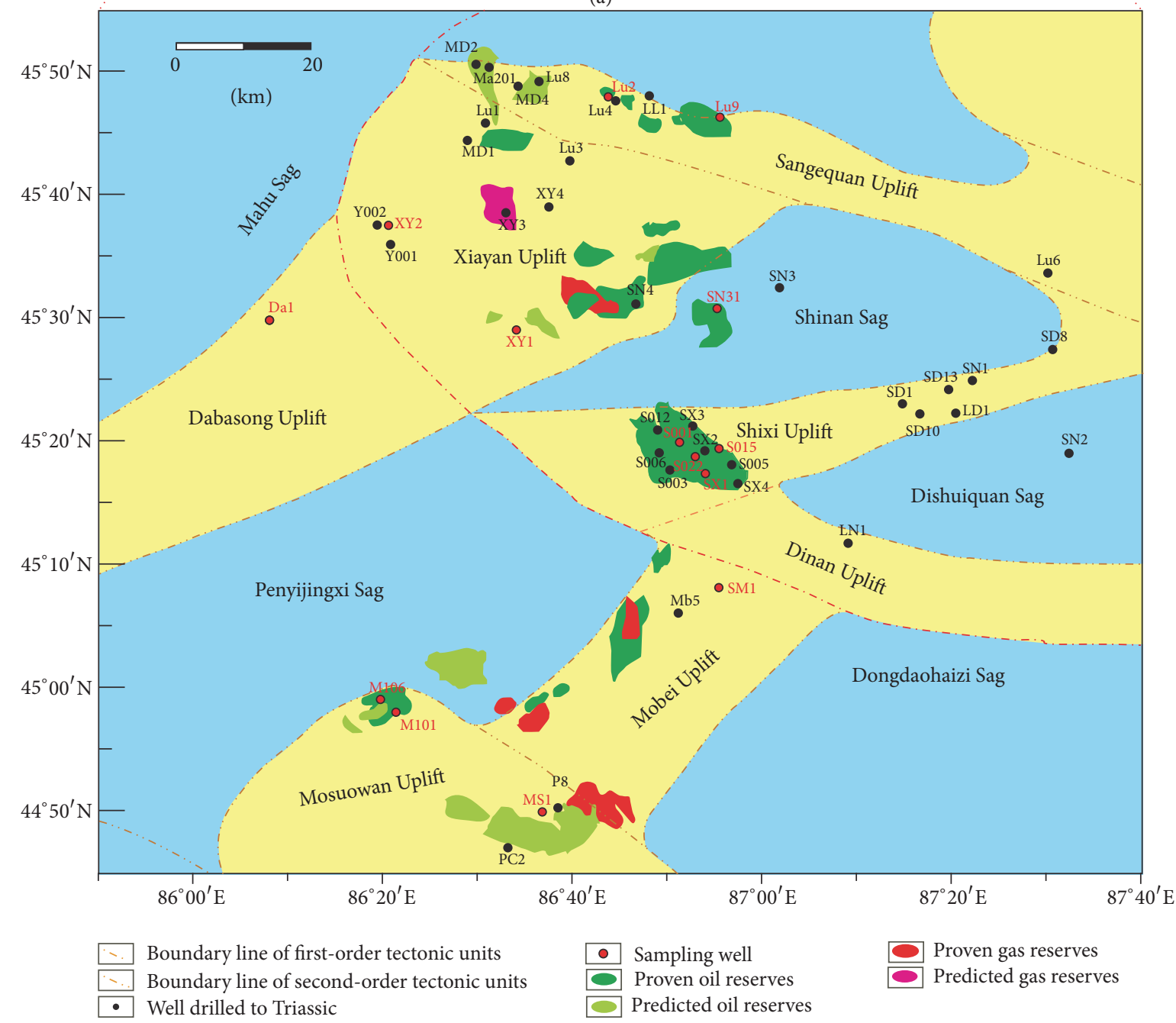

(b)

Figure 1: (a) Structural units of the Junggar Basin and (b) structural units and key wells of the studied central basin. 


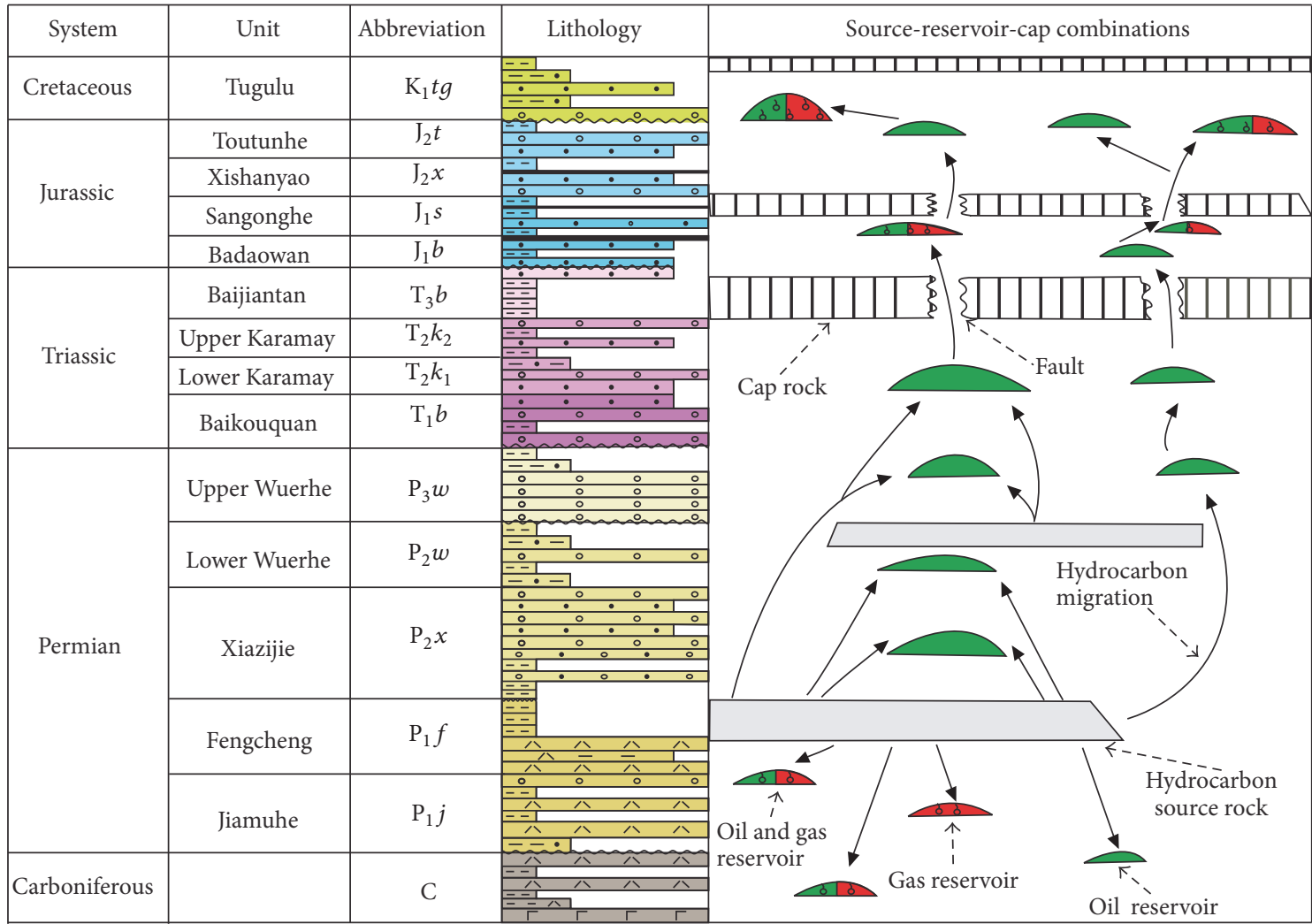

\begin{tabular}{|c|c|c|c|c|c|}
\hline \begin{tabular}{|l|}
0000 \\
0000 \\
0000 \\
\end{tabular} & Conglomerate & 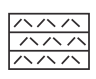 & Tuff & 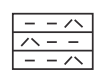 & Tuffaceous mudstone \\
\hline \begin{tabular}{|l}
$\Gamma r\ulcorner$ \\
$\Gamma r \Gamma$ \\
$г \Gamma \Gamma$ \\
\end{tabular} & Basalt & \begin{tabular}{|l|}
$\cdots$ \\
$\cdots$ \\
\end{tabular} & Fine-grained sandstone & \begin{tabular}{|l|}
$--\dot{ }$ \\
$\dot{--}$
\end{tabular} & Sandy mudstone \\
\hline \begin{tabular}{|l|l|}
$0.0 \cdot$ \\
0.0 \\
0.0 \\
\end{tabular} & Sandy conglomerate & & Coal seam & \begin{tabular}{|l|}
--- \\
--- \\
--
\end{tabular} & Mudstone \\
\hline
\end{tabular}

FIGURE 2: Generalized stratigraphy and source-reservoir-cap rock combinations in the central Junggar Basin.

TABLE 1: Bulk geochemical parameters of Triassic potential mudstone source rocks in the central Junggar Basin.

\begin{tabular}{|c|c|c|c|c|c|c|c|c|c|c|c|c|}
\hline Well & $\begin{array}{c}\text { Depth } \\
\text { (m) }\end{array}$ & Fm. & Lithology & $\begin{array}{c}\text { TOC } \\
(\%)\end{array}$ & $\begin{array}{c}\delta^{13} \mathrm{C}^{1} \\
(\% 0)\end{array}$ & $\begin{array}{c}\delta^{13} C^{2} \\
(\% 0)\end{array}$ & $\begin{array}{c}S_{1} \\
(\mathrm{mg} / \mathrm{g})\end{array}$ & $\begin{array}{c}S_{2} \\
(\mathrm{mg} / \mathrm{g})\end{array}$ & $\begin{array}{c}\text { PG } \\
(\mathrm{mg} / \mathrm{g})\end{array}$ & $\begin{array}{c}\mathrm{HI} \\
(\mathrm{mg} / \mathrm{g})\end{array}$ & $R_{o}(\%)$ & $\begin{array}{l}T_{\max } \\
\left({ }^{\circ} \mathrm{C}\right)\end{array}$ \\
\hline SM 1 & 4180 & $\mathrm{~T}_{3} b$ & $\begin{array}{l}\text { Dark gray } \\
\text { mudstone }\end{array}$ & 1.17 & -26.81 & -28.47 & 0.40 & 1.84 & 2.24 & 157.26 & 0.79 & 440 \\
\hline SM 1 & 4190 & $\mathrm{~T}_{3} b$ & $\begin{array}{l}\text { Dark gray } \\
\text { mudstone }\end{array}$ & 1.49 & -26.58 & -28.14 & 0.61 & 2.90 & 3.51 & 194.63 & 0.80 & 444 \\
\hline SM 1 & 4200 & $\mathrm{~T}_{3} b$ & $\begin{array}{l}\text { Dark gray } \\
\text { mudstone }\end{array}$ & 1.26 & -25.70 & -26.30 & 0.36 & 1.68 & 2.04 & 133.33 & 0.82 & 442 \\
\hline SM 1 & 4210 & $\mathrm{~T}_{3} b$ & $\begin{array}{l}\text { Dark gray } \\
\text { mudstone }\end{array}$ & 1.34 & -26.12 & -28.45 & 0.69 & 3.67 & 4.36 & 273.88 & 0.83 & 444 \\
\hline SM 1 & 4218 & $\mathrm{~T}_{3} b$ & $\begin{array}{l}\text { Dark gray } \\
\text { mudstone }\end{array}$ & 1.36 & -27.08 & -29.65 & 0.56 & 2.88 & 3.44 & 211.76 & 0.83 & 445 \\
\hline SM 1 & 4230 & $\mathrm{~T}_{3} b$ & $\begin{array}{l}\text { Dark gray } \\
\text { mudstone }\end{array}$ & 1.40 & -26.73 & -29.09 & 0.98 & 4.82 & 5.80 & 211.76 & 0.85 & 443 \\
\hline SM 1 & 4294 & $\mathrm{~T}_{3} b$ & $\begin{array}{l}\text { Dark gray } \\
\text { mudstone }\end{array}$ & 1.57 & -28.86 & -30.46 & 0.40 & 1.96 & 2.36 & 124.84 & 0.88 & 445 \\
\hline SM 1 & 4324 & $\mathrm{~T}_{2} k$ & $\begin{array}{l}\text { Dark gray } \\
\text { mudstone }\end{array}$ & 1.02 & -26.33 & -28.01 & 0.43 & 2.22 & 2.65 & 217.65 & 0.90 & 446 \\
\hline
\end{tabular}

Note. 1, kerogen carbon isotope; 2 , carbon isotope of rock extracts. 


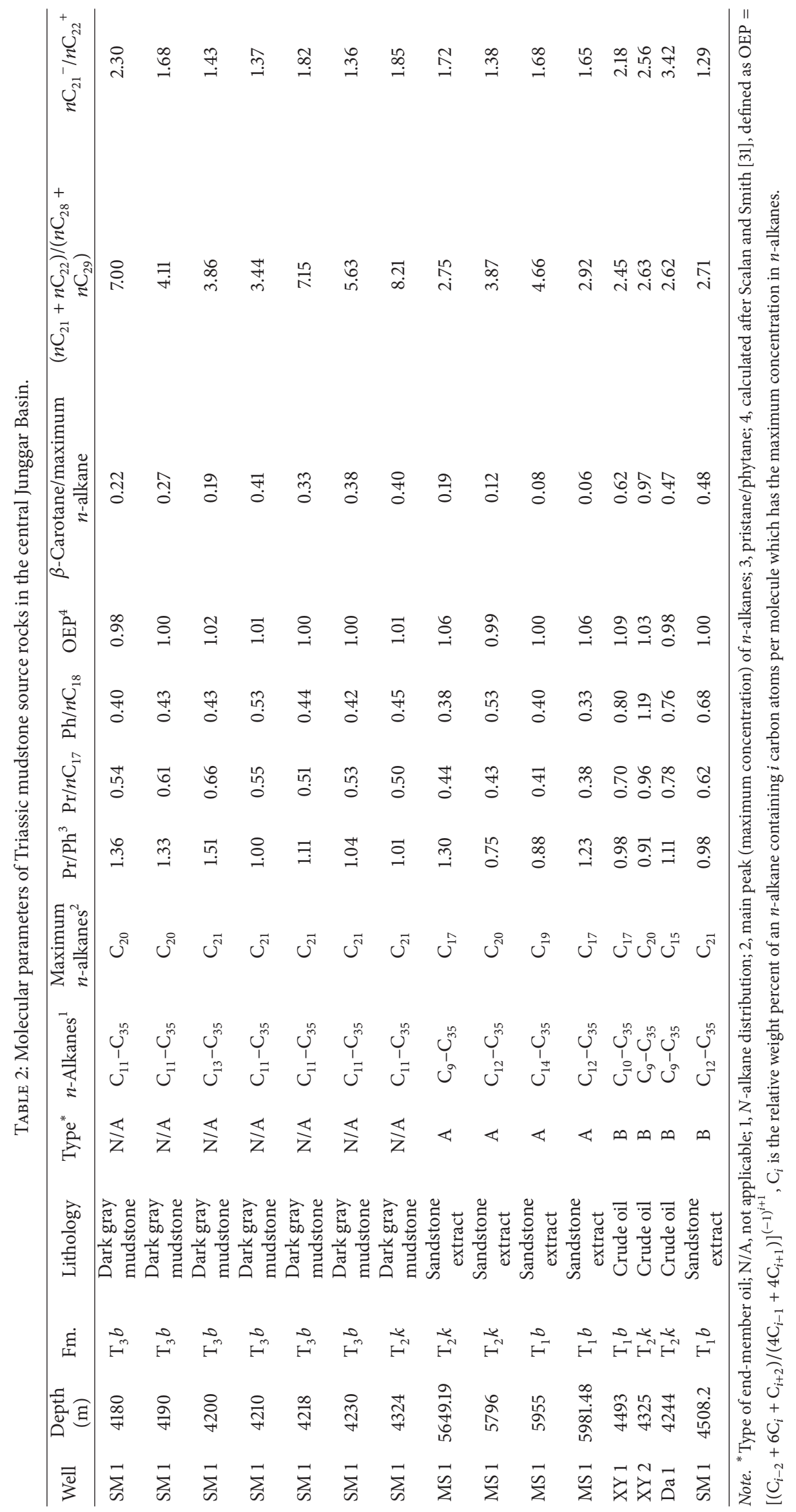


Source rocks and reservoir samples were crushed by the use of a handheld jaw crusher and a shatter box. The powders were then extracted using Soxhlet apparatus by a mixture of dichloromethane: methanol $(93: 7)$ for $72 \mathrm{~h}$. The rock extracts were evaporated through rotary evaporation and dried using nitrogen gas. Then the dried extracts were weighed. Then, asphaltenes were removed from the rock extracts and the three crude oils by precipitation with hexane, followed by filtration. The deasphalted extracts and oils were subsequently separated into saturated hydrocarbons, aromatic hydrocarbons, and polar compound (NSO) through column chromatography, using hexane, a mixture of dichloromethane and hexane $(1: 1)$, and a mixture of dichloromethane and methanol $(1: 1)$. The alkanes were analyzed by gas chromatography-mass spectrometry (GC-MS). GC-MS analysis was carried out using an Agilent 5975 interfaced to an Agilent 6890 chromatograph fitted with a $30 \mathrm{~m} \times 0.32 \mathrm{~mm}$ i.d. HP-5 column with a film thickness of $0.25 \mu \mathrm{m}$, and $\mathrm{He}$ was used as carrier gas. The GC oven temperature was held initially at $75^{\circ} \mathrm{C}(2 \mathrm{~min})$, ramped from 75 to $200^{\circ} \mathrm{C}$ at $5^{\circ} \mathrm{C} / \mathrm{min}$, and finally ramped to $310^{\circ} \mathrm{C}$ at $3^{\circ} \mathrm{C} / \mathrm{min}$ (held for $8 \mathrm{~min}$ ). The GC-MS system was operated in the electron impact (EI) mode at electron energy of $70 \mathrm{eV}$, with an emission current of $200 \mu \mathrm{A}$. The data acquisition mode is selected iron model (SIM).

For the stable carbon isotopic analysis of the crude oils, mudstone kerogen, and rock extracts, the samples were added to a quartz tube with $\mathrm{CuO}$ wire $(1.0 \mathrm{~g})$ and were then combusted at $500^{\circ} \mathrm{C}$ for $1 \mathrm{~h}$ and $850^{\circ} \mathrm{C}$ for another $3 \mathrm{~h}$. Isotopic ratios were analyzed using cryogenically purified $\mathrm{CO}_{2}$ in a Finnigan MAT-253 mass spectrometer and are reported in standard $\delta$-notation relative to the Vienna Pee Dee Belemnite (VPDB) standard. The working standard used was NBS-19.

For comparison, analytical results of some typical Permian-derived oils and Jurassic mudstone source rocks are retrieved from the geochemical database of PetroChina Xinjiang Oilfield Company. Note that there are no effective Permian source rocks available in the study area because rocks in the sag area are too deep to drill. Thus, to compensate, we use the Permian-derived oils to indicate the characteristics of source rock.

\section{Results and Discussion}

4.1. Basic Geochemical Characteristics of Triassic Potential Mudstone Source Rocks. Table 1 presents the basic geochemical characteristics of the Triassic possible source rocks in this study. Results show that the mudstones are organic-rich [38], shown by TOC values higher than $1.0 \%$ and petroleum generation $\left(\mathrm{PG}=S_{1}+S_{2}\right)$ contents higher than $2.0 \mathrm{mg} / \mathrm{g}$ rock. HI values of these samples are $>100 \mathrm{mg} / \mathrm{g}$ TOC, the kerogen $\delta^{13} \mathrm{C}$ value ranges from $-28.86 \%$ to $-25.70 \%$, and the $\delta^{13} \mathrm{C}$ value of the mudstone extracts varies between $-26.30 \%$ and $-30.46 \%$. These are indicative of type III kerogen in general and some having high $\mathrm{HI}$ values can be relatively oil-prone [38]. $R_{o}$ and $T_{\max }$ values of these samples are generally in the range of $0.79-0.90 \%$ and $440-446^{\circ} \mathrm{C}$, respectively, implying that the organic matters in the mudstones have entered the oil-generation window [38]. Thus, the mudstones can generate both oil and gas and be regarded as potential source rocks.

4.2. Biomarkers of Triassic Potential Mudstone Source Rocks and Their Difference to the Permian and Jurassic Source Rocks. The biomarker composition of the eight Triassic mudstones in this study is similar and can be distinguished from the other three identified source rocks present in the central Junggar Basin (i.e., the Permian two sequences and Jurassic), setting up a good foundation for oil-source correlation and mixing calculation (Figure 3, Tables 2 and 3).

In terms of paraffin compositions, the Triassic mudstones have a carbon number of $n$-alkanes ranging from $\mathrm{C}_{11}$ to $\mathrm{C}_{35}$, peaking at $n-\mathrm{C}_{20}$ or $n-\mathrm{C}_{21}$. The ratios of $\mathrm{Pr} / \mathrm{Ph}, \mathrm{Pr} / n-\mathrm{C}_{17}$, and $\mathrm{Ph} / n-\mathrm{C}_{18}$ range in $1.00-1.51$ (averages at 1.19), 0.50-0.66 (averages at 0.56 ), and $0.40-0.53$ (averages at 0.44 ), respectively, implying type II-III kerogen mixtures (Figure 4) [39]. This is consistent with the understanding obtained from the basic geochemistry above (Section 4.1). The ratio of $\beta$-carotane $/ n$ alkane main peak ranges in $0.19-0.47$ with an average of 0.34 , suggesting that the water body of the depositional environment has certain salinity, potentially stratifying water column which provides favorable preservation of organic matter [40]. These characteristics are generally similar to typical Permianderived oils, which are indicative of Permian mudstone source rocks (Figures 3 and 4), but are fundamentally different from typical Jurassic mudstone source rocks in the study area, which are commonly characterized by $\mathrm{Pr} / \mathrm{Ph}$ values $>$ 3.0 and low to no concentration of carotanes (Figures 3 and $4)$.

As for terpanes, the abundance of tricyclic terpanes (TTs) is relatively less than pentacyclic terpanes (PTs), with the ratio of main TT peak to main PT peak ranging between 0.21 and 0.34 with an average of 0.24 . This implies that the organic matter in the Triassic mudstones is moderately mature in general and has a relatively big contribution from higher plants and/or prokaryotes regarding bioprecursors [3, 41]. Such characteristics are sharply different from the Jurassic mudstone source rocks in the study area, which have extremely low abundance of TTs relative to PTs (the ratio of TTs/PTs commonly less than 0.1; Figure 3(a)). Among the TT compounds, $\mathrm{C}_{19}$ TT has a relatively high abundance, such that the ratios of $\mathrm{C}_{19} \mathrm{TT} / \mathrm{C}_{21} \mathrm{TT}$ and $\mathrm{C}_{19} \mathrm{TT} / \mathrm{C}_{23} \mathrm{TT}$ were around 0.2 ; this is also different from the characteristics of the Jurassic mudstone source rocks in the study area (Figures 3(c) and $3(\mathrm{~d})$ ). No defined distribution pattern of $\mathrm{C}_{20}, \mathrm{C}_{21}$, or $\mathrm{C}_{23}$ TT can be observed, which is commonly regarded as a fingerprint of Permian-sourced oils indicative of source rocks in the study area [42]. The ratios of $\mathrm{C}_{24} \mathrm{TeT} / \mathrm{C}_{26} \mathrm{TT}, \mathrm{Ts} / \mathrm{Tm}$, and gammacerane $/ \mathrm{C}_{30}$ hopane average at $0.65,0.51$, and 0.12 , respectively, indicative of a dual input of terrigenous higher plants and aquatic organisms from lacustrine environments [3, 21, 22]. These values provide clues to distinguish the Triassicderived oils from the Permian- and Jurassic-derived oils in the study area (Table 4).

In terms of the sterane composition, the Triassic mudstone source rocks have relatively high abundance of pregnane and homopregnanes, as indicated by a pregnane $/ \alpha \alpha \alpha \mathrm{C}_{29} R$ 


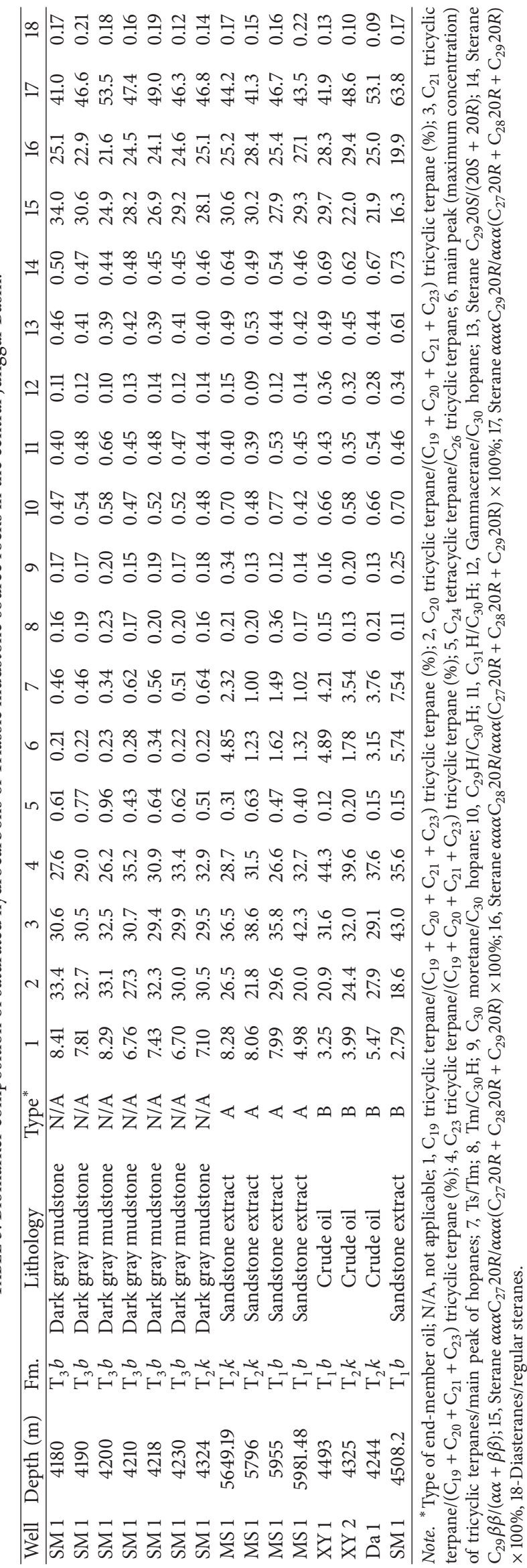


SM 1 well, $4218 \mathrm{~m}, \mathrm{~T}_{3} b$, dark gray mudstone,

$\mathrm{TOC}=1.36 \%, \mathrm{PG}=3.44 \mathrm{mg} / \mathrm{g}, \mathrm{HI}=211.76 \mathrm{mg} / \mathrm{g}$,

$\delta^{13} \mathrm{C}=-29.65 \%, \operatorname{Pr} / \mathrm{Ph}=1.11$,

$R_{o}=0.83, T_{\max }=445^{\circ} \mathrm{C}, \mathrm{C}_{29} 20 \mathrm{~S} /(20 S+20 R)=0.39$.

GC

$m / z=191$

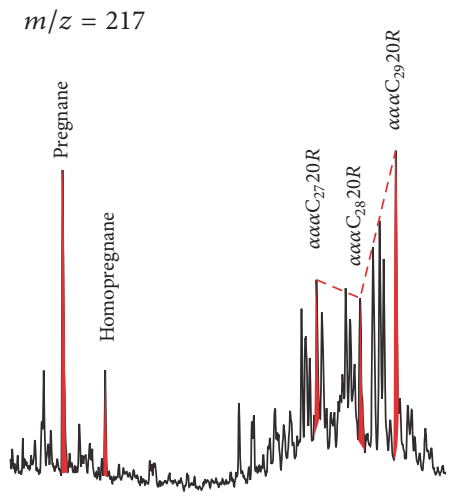

(a) Triassic mudstone source rock

MO 008 well, $2926 \mathrm{~m}, \mathrm{~J}_{1} s$, carbonaceous mudstone,

TOC $=5.87 \%, P G=4.93 \mathrm{mg} / \mathrm{g}, \mathrm{HI}=81.09 \mathrm{mg} / \mathrm{g}$,

$\delta^{13} \mathrm{C}=-26.40 \%, \operatorname{Pr} / \mathrm{Ph}=5.6$,

$R_{o}=1.0 \%, T_{\max }=443^{\circ} \mathrm{C}, \mathrm{C}_{29} 20 \mathrm{~S} /(20 \mathrm{~S}+20 R)=0.40$.

GC

$m / z=191$

$m / z=217$

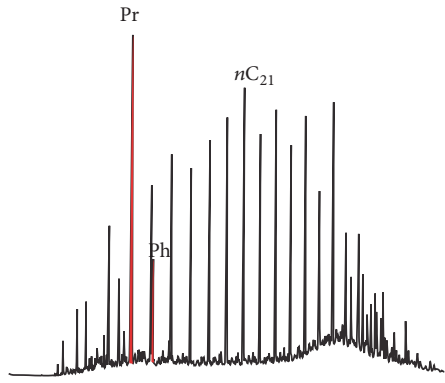

M13 well, $4546 \mathrm{~m}, \mathrm{~J}_{1} s_{2}{ }^{2}$, crude oil,

Density $=0.84 \mathrm{~g} / \mathrm{cm}^{3}$,

Saturate hydrocarbons $=81.02 \%$, aromatic hydrocarbons $=8.25 \%, \mathrm{NSO}=3.01 \%$, asphaltene $=1.27 \%$,

$\delta^{13} \mathrm{C}=-29.30 \%, \mathrm{Pr} / \mathrm{Ph}=1.33, \mathrm{C}_{29} 20 S /(20 S+20 R)=0.48$.

GC

$m / z=191$

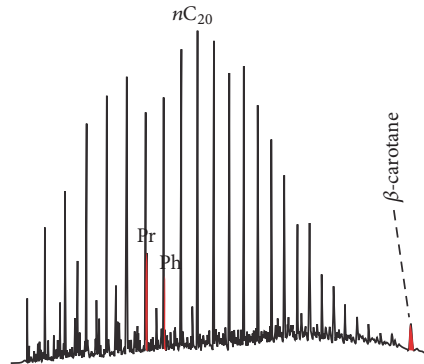

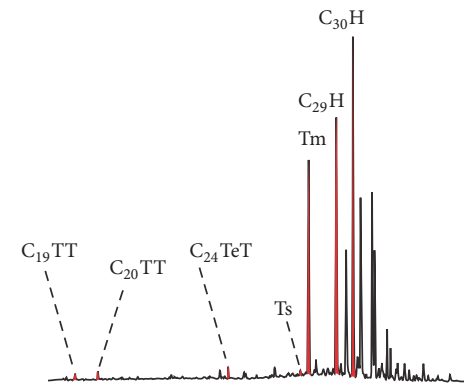

(b) Jurassic mudstone source rock $m / z=217$

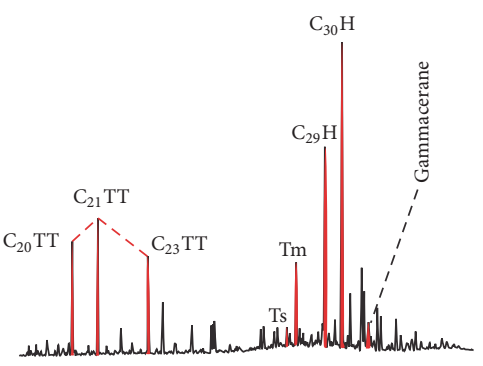

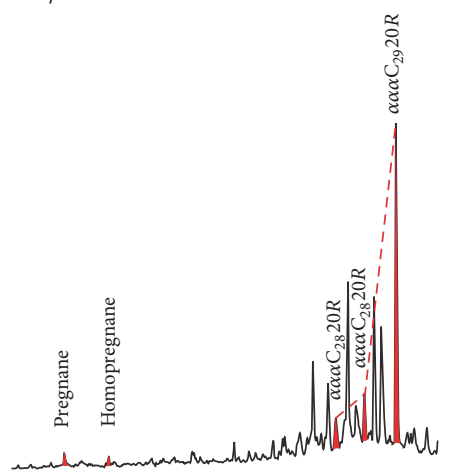

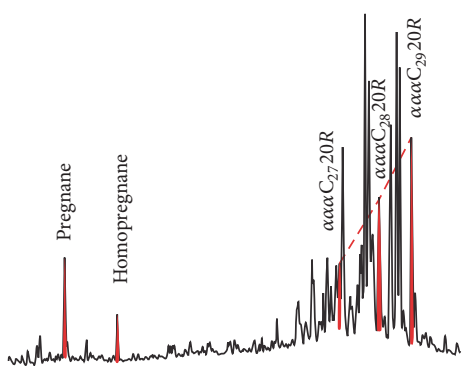

(c) $P_{2} w$ mudstone source rock

Figure 3: Continued. 

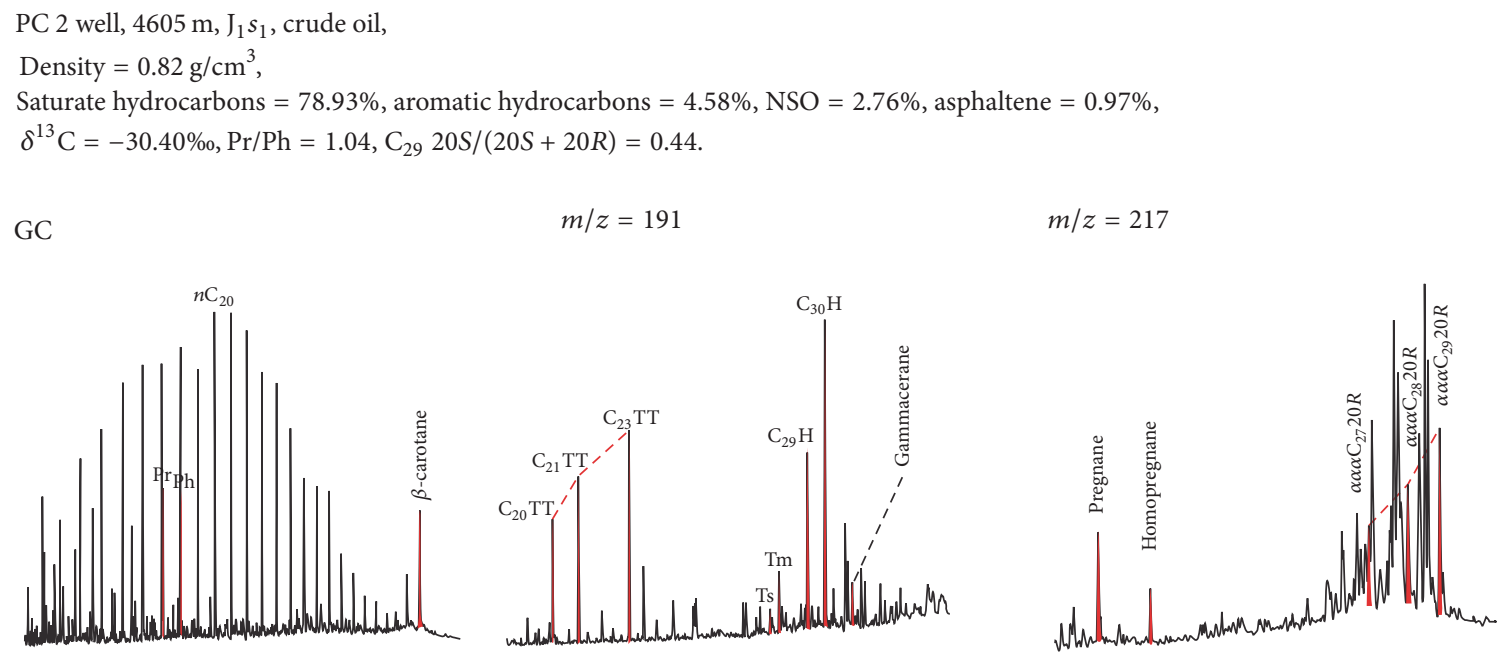

(d) $P_{1} f$ mudstone source rock

Figure 3: Gas chromatograms (GC) and GC-mass spectra (MS) of Triassic, Jurassic, and Permian mudstone source rocks in the central Junggar Basin. (a) Triassic mudstone source rock; (b) Jurassic mudstone source rock; (c) $\mathrm{P}_{2} w$-derived oil indicating $\mathrm{P}_{2} w$ mudstone source rock; (d) $\mathrm{P}_{1} f$-derived oil indicating $\mathrm{P}_{1} f$ mudstone source rock.

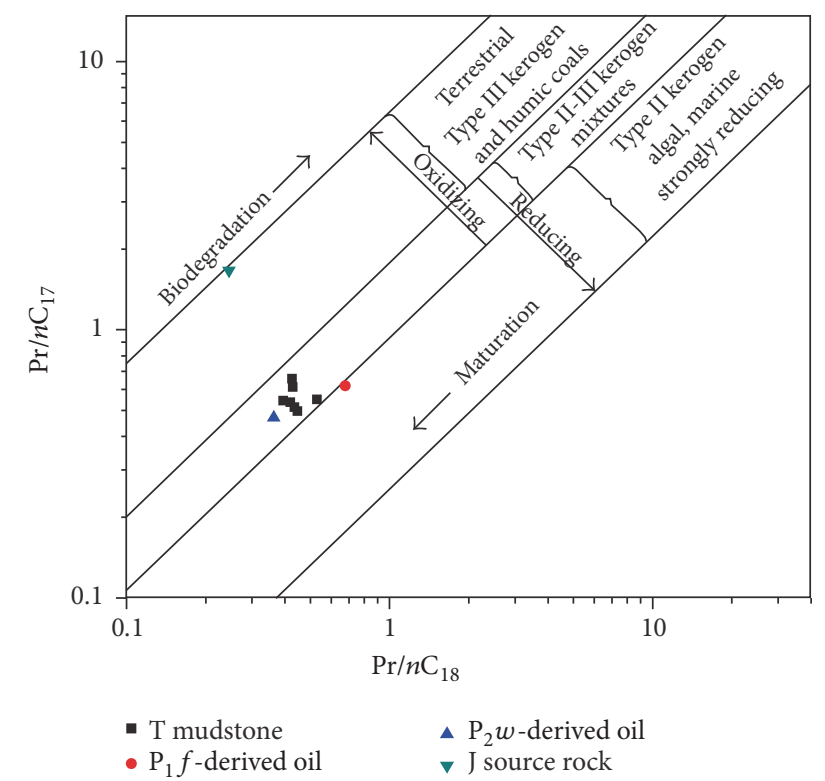

Figure 4: $\mathrm{Ph} / n-\mathrm{C}_{18}$ versus $\mathrm{Pr} / n-\mathrm{C}_{17}$ of the Triassic mudstone source rocks collected in this study. Average values of Permian-derived oils and Jurassic mudstone source rocks are plotted for comparison.

regular sterane ratio of nearly 1.0. Among $\mathrm{C}_{27}, \mathrm{C}_{28}$, and $\mathrm{C}_{29}$ regular steranes, $\mathrm{C}_{29}$ was the most abundant, as its percentage among the three regular steranes is between $41.0 \%$ and $53.5 \%$; in addition, the abundance of the $\mathrm{C}_{27}$ sterane is higher than that of the $\mathrm{C}_{28}$ sterane, as indicated by their relative contents among the three regular steranes being $24.9-34.0 \%$ and $21.6-25.1 \%$, respectively. These features are also suggestive of nonmarine shales [43]. These mudstones have relatively low level of diasteranes to regular steranes, with a ratio being 0.12-0.21. High diasteranes/regular steranes are typical of petroleum derived from clay-rich mineral [44, 45]. Also, alternatively, acidic and oxic conditions facilitate diasterane formation $[46,47]$. Thus, the low values of diasteranes/regular steranes of the Triassic mudstone probably are indicative of reduced to suboxic depositional environment.

In summary, the Triassic mudstone source rocks can be distinguished from Permian and Jurassic mudstone source rocks in five aspects (Table 4, Figure 5). Note that these parameters should be used in integration but not individually.

(1) Carbon Isotope. Compared to Permian-derived hydrocarbons indicative of source rocks $\left(\mathrm{P}_{1} f<-30 \%, \mathrm{P}_{2} w<-28 \%\right.$, $\mathrm{PDB})$ and Jurassic mudstone source rocks $(>-28 \%$, PDB), the $\delta^{13} \mathrm{C}$ value of the Triassic mudstone source rocks is distributed in $-30.46 \%$ o $-26.30 \%$, which is generally heavier than Jurassic mudstone source rocks and lighter than Permian-derived hydrocarbons and associated mudstone source rocks, indicative of different depositional environments and organic matter precursors.

(2) Paraffin Composition. The Pr/Ph value of the Triassic mudstone source rocks ranges between 1.0 and 2.0, which is similar to the $\mathrm{P}_{2} w$-derived hydrocarbons and associated mudstone source rocks, higher than the $\mathrm{P}_{1} f$-derived hydrocarbons and associated mudstone source rocks $(<1.0)$ and lower than Jurassic mudstone source rocks $(>3.0)$.

(3) $\beta$-Carotane Abundance. The value $\beta$-carotane/maximum $n$-alkanes of the Triassic mudstone source rocks is between 0.2 and 0.4 , which is lower than the $\mathrm{P}_{1} f$-derived hydrocarbons and associated mudstone source rocks $(>0.4)$ and higher than Jurassic-derived hydrocarbons and associated mudstone source rocks $(<0.2)$.

(4) Terpanes Composition. Compared to Jurassic mudstone source rocks, the ratios of TTs/PTs of Triassic mudstone 
TABLE 4: Key geochemical differences between Triassic mudstone source rocks and other three identified end-member source rocks (i.e., Jurassic and Permian) in the central Junggar Basin.

\begin{tabular}{|c|c|c|c|c|c|}
\hline \multicolumn{2}{|c|}{ End-member source rocks } & $\mathrm{T}$ & $\mathrm{J}$ & $\mathrm{P}_{2} w$ & $\mathrm{P}_{1} f$ \\
\hline \multicolumn{2}{|r|}{$\delta^{13} \mathrm{C}$} & $-26 \%$ $-30 \%$ & $>-28 \% 0$ & $<-28 \%$ & $<-30 \%$ \\
\hline \multirow{3}{*}{ Paraffins } & $\begin{array}{l}\text { Main peak (maximum } \\
\text { concentration) of } n \text {-alkanes }\end{array}$ & $\mathrm{C}_{20}, \mathrm{C}_{21}$ & Mostly $\mathrm{C}_{23}$ or $\mathrm{C}_{25}$ & $\mathrm{C}_{19}, \mathrm{C}_{20}$ & $\mathrm{C}_{17}$ \\
\hline & $\mathrm{Pr} / \mathrm{Ph}$ & $1.0-2.0$ & $>3.0$ & $1.0-2.0$ & $<1.0$ \\
\hline & $\begin{array}{l}\mathrm{Pr} / n-\mathrm{C}_{17} \\
\mathrm{Ph} / n-\mathrm{C}_{18}\end{array}$ & $0.3-0.6$ & $\begin{array}{l}\mathrm{Pr} / n-\mathrm{C}_{17}>1.0 \\
\mathrm{Ph} / n-\mathrm{C}_{18}<0.5\end{array}$ & $0.3-0.6$ & $>0.5$ \\
\hline$\beta$-Carotane & $\beta$-Carotane/maximum $n$-alkane & $0.2-0.4$ & Very less/no & $<0.2$ & $>0.4$ \\
\hline \multirow{7}{*}{ Terpanes } & $\mathrm{C}_{19} / \mathrm{C}_{21} \mathrm{TT}$ & $<0.2$ & $>1.0$ & $<0.2$ & $<0.2$ \\
\hline & $\mathrm{C}_{19} / \mathrm{C}_{23} \mathrm{TT}$ & $<0.2$ & $>1.0$ & $<0.3$ & $<0.2$ \\
\hline & $\begin{array}{l}\text { Distribution pattern of } \mathrm{C}_{20}, \mathrm{C}_{21} \\
\quad \text { or } \mathrm{C}_{23} \mathrm{TT}\end{array}$ & $\begin{array}{c}\text { No defined } \\
\text { distribution pattern }\end{array}$ & $\begin{array}{l}\mathrm{C}_{20}>\mathrm{C}_{21}>\mathrm{C}_{23} \\
\mathrm{C}_{20}>\mathrm{C}_{21}<\mathrm{C}_{23}\end{array}$ & $\mathrm{C}_{20}<\mathrm{C}_{21}>\mathrm{C}_{23}$ & $\mathrm{C}_{20}<\mathrm{C}_{21}<\mathrm{C}_{23}$ \\
\hline & $\begin{array}{c}\text { Main peak of TT/main peak of } \\
\text { hopanes }\end{array}$ & $<0.5$ & $<0.1$ & $0.2-1.0$ & $0.2-1.0$ \\
\hline & $\mathrm{C}_{24} \mathrm{TeT} / \mathrm{C}_{26} \mathrm{TT}$ & $>0.5$ & $>3.0$ & $0.2-0.5$ & $<0.3$ \\
\hline & Gammacerane/ $\mathrm{C}_{30}$ hopane & $\sim 0.1$ & Very less/no & $<0.2$ & $>0.3$ \\
\hline & $\mathrm{Ts} / \mathrm{Tm}$ & $<1.0$ & $<0.1$ & $<0.5$ & $<0.5$ \\
\hline \multirow[t]{2}{*}{ Steranes } & $\begin{array}{l}\mathrm{C}_{27}, \mathrm{C}_{28}, \mathrm{C}_{29} \\
\text { regular steranes }\end{array}$ & $\begin{array}{l}\text { Predominance of } C_{29} \\
=40-60 \%, C_{27}>C_{28}\end{array}$ & $\begin{array}{c}\text { Predominance of } \\
\mathrm{C}_{29}>70 \%, \mathrm{C}_{27}<\mathrm{C}_{28}\end{array}$ & $\begin{array}{c}\text { Predominance } \\
\text { of } \mathrm{C}_{29}= \\
40-50 \% \text {, } \\
\text { generally } \mathrm{C}_{27}< \\
\mathrm{C}_{28}\end{array}$ & $\begin{array}{c}\text { Predominance } \\
\text { of } \mathrm{C}_{29}= \\
40-60 \% \text {, } \\
\text { generally } \mathrm{C}_{27}< \\
\mathrm{C}_{28}\end{array}$ \\
\hline & Diasteranes/regular steranes & $0.1-0.2$ & $>0.4$ & $<0.4$ & $<0.4$ \\
\hline
\end{tabular}

source rocks are higher $(0.2-1.0)$. The values of $\mathrm{C}_{19} \mathrm{TT} / \mathrm{C}_{21} \mathrm{TT}$ and $\mathrm{C}_{19} \mathrm{TT} / \mathrm{C}_{23}$ TT are both less than 0.2 , which is also different from the characteristics of the Jurassic mudstone source rocks in the study area $(>1.0)$. Ts/Tm values of Triassic mudstone source rocks $(<0.4)$ are obviously higher than Jurassic mudstone source rocks $(<0.1)$. Compared to Permian-derived hydrocarbons indicative of source rocks, no defined distribution pattern of $\mathrm{C}_{20}, \mathrm{C}_{21}$, or $\mathrm{C}_{23}$ TT can be observed in Triassic mudstone source rocks, which is commonly regarded as a fingerprint of Permian-sourced oils indicative of source rocks in the study area $\left(\mathrm{C}_{20}<\mathrm{C}_{21}>\mathrm{C}_{23}\right.$ for $\mathrm{P}_{2} w$ and $\mathrm{C}_{20}<\mathrm{C}_{21}<\mathrm{C}_{23}$ for $\left.\mathrm{P}_{1} f\right)$ [48]. The value of gammacerane/ $\mathrm{C}_{30}$ hopane is also generally less than $\mathrm{P}_{1} f$-sourced hydrocarbons indicative of source rocks $(>0.3)$. The ratio of $\mathrm{C}_{24} \mathrm{TeT} / \mathrm{C}_{26} \mathrm{TT}$ of Triassic mudstone source rocks $(>0.5)$ is higher than Permiansourced hydrocarbons indicative of source rocks $(0.2-0.5)$ but not as high as Jurassic mudstone source rocks $(>3.0)$.

(5) Steranes Composition. Similar to Permian and Jurassic mudstone source rocks, Triassic mudstone source rocks also have a predominance of $\mathrm{C}_{29}$ steranes but the percent of $\mathrm{C}_{29}$ steranes is much less than Jurassic mudstone source rocks. Value of diasteranes/steranes of Triassic mudstone source rocks $(0.1-0.2)$ is also much less than Jurassic mudstone source rocks $(>0.4)$. Triassic mudstone source rocks show a distinct feature of $\mathrm{C}_{27}>\mathrm{C}_{28}$ steranes which are not observed in Permian and Jurassic mudstone source rocks.

\subsection{Geochemistry of Triassic-Reservoired Oils and Reservoir Extracts}

4.3.1. General Geochemistry. As shown in Table 5, the Triassic-reservoired oils collected in this study have a density of $0.81-0.86 \mathrm{~g} / \mathrm{cm}^{3}$, a viscosity of $2.98-10.69 \mathrm{mPa} \cdot \mathrm{s}$, and high abundance of wax compounds (3.82-14.08\%). Thus, these oils are light oils with low viscosity, which is consistent with high concentrations of saturated hydrocarbons ( $>75 \%)$, aromatic hydrocarbons (4.43-16.23\%), and low concentrations of NSO and asphaltene $(<5 \%)$ in terms of group compositions.

The abundance of reservoir extracts is all above $1000 \mathrm{ppm}$ with a maximum of $11035 \mathrm{ppm}$. In terms of group compositions, a relatively large variation is observed; for example, the content of saturated hydrocarbons ranges between 52 and $92 \%$, while asphaltenes vary between 0.75 and $10.08 \%$. This variation implies that the reservoired hydrocarbons may have experienced complex secondary alterations, such as water washing, biodegradation, and oxidation $[49,50]$.

The bulk $\delta^{13} \mathrm{C}$ of the crude oils and extracts range within $-30.27 \%$ o $-27.75 \%$.

4.3.2. Biomarkers. As shown in Figure 6 and Tables 2 and 3, the biomarker compositions of the Triassic-reservoired crude oils and reservoir extracts in the study area can be generally divided into two types. Note that molecular compositions of oil are influenced by maturity and secondary alterations [3]. 


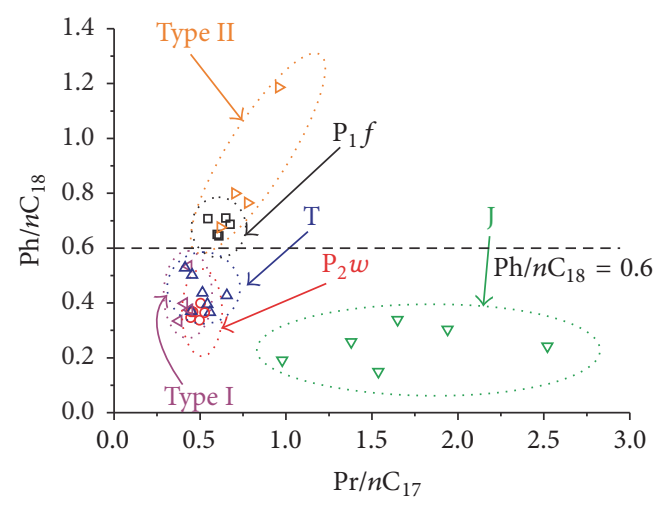

$\nabla \mathrm{J}$ mudstone source rock $\quad \square \mathrm{P}_{1} f$ mudstone source rock

$\Delta$ T mudstone source rock $\triangleleft$ Type A hydrocarbon

- $\mathrm{P}_{2} w$ mudstone source rock $\triangleright$ Type $\mathrm{B}$ hydrocarbon

(a)

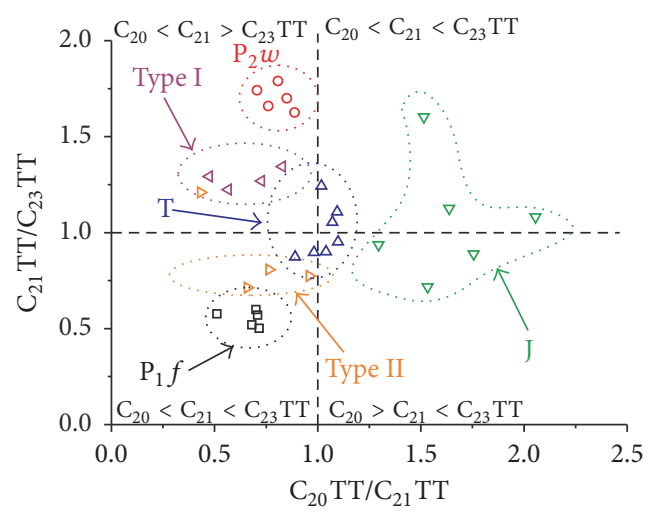

$\nabla \mathrm{J}$ mudstone source rock $\quad \square \mathrm{P}_{1} f$ mudstone source rock

$\Delta$ T mudstone source rock $\triangleleft$ Type A hydrocarbon

- $\mathrm{P}_{2} w$ mudstone source rock $\triangleright$ Type $\mathrm{B}$ hydrocarbon

(c)

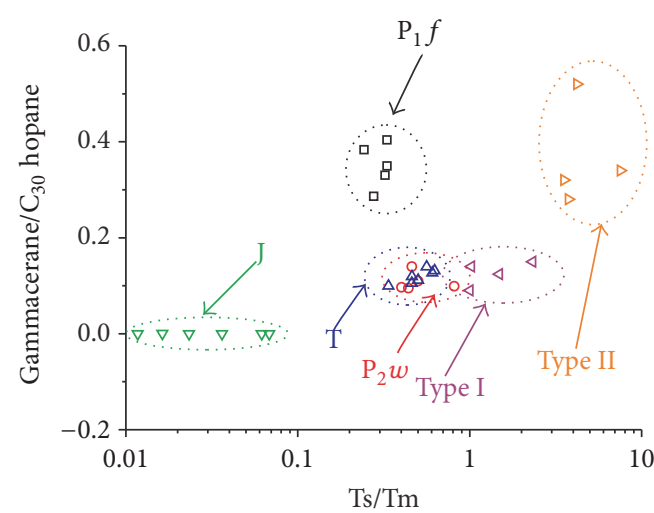

$\begin{array}{ll}\nabla \text { J mudstone source rock } & \square \mathrm{P}_{1} f \text { mudstone source rock } \\ \Delta \text { T mudstone source rock } & \triangleleft \text { Type A hydrocarbon } \\ \circ \mathrm{P}_{2} w \text { mudstone source rock } & \triangleright \text { Type } \mathrm{B} \text { hydrocarbon }\end{array}$

(e)

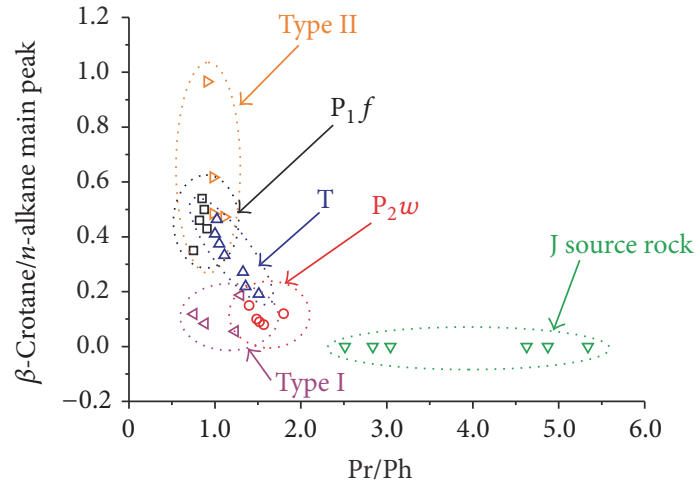

$\begin{array}{ll}\nabla \text { J mudstone source rock } & \square \mathrm{P}_{1} f \text { mudstone source rock } \\ \Delta \text { T mudstone source rock } & \triangleleft \text { Type A hydrocarbon } \\ \circ \mathrm{P}_{2} w \text { mudstone source rock } & \triangleright \text { Type B hydrocarbon }\end{array}$

(b)

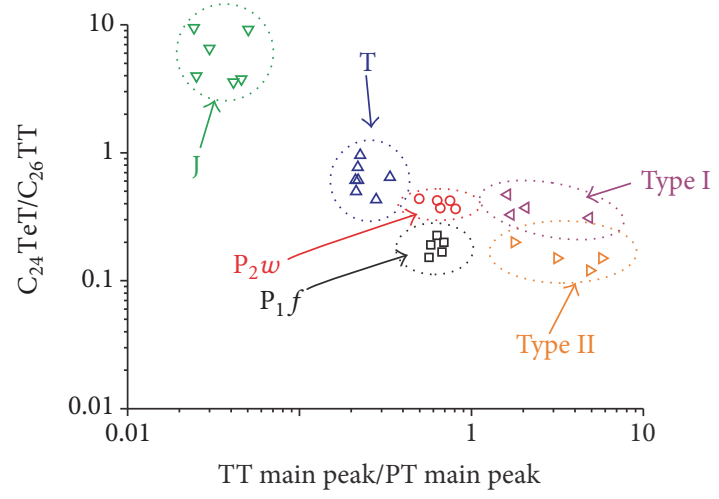

$\begin{array}{ll}\nabla \text { J mudstone source rock } & \square \mathrm{P}_{1} f \text { mudstone source rock } \\ \Delta \text { T mudstone source rock } & \triangleleft \text { Type A hydrocarbon } \\ \circ \mathrm{P}_{2} w \text { mudstone source rock } & \triangleright \text { Type } \mathrm{B} \text { hydrocarbon }\end{array}$

(d)

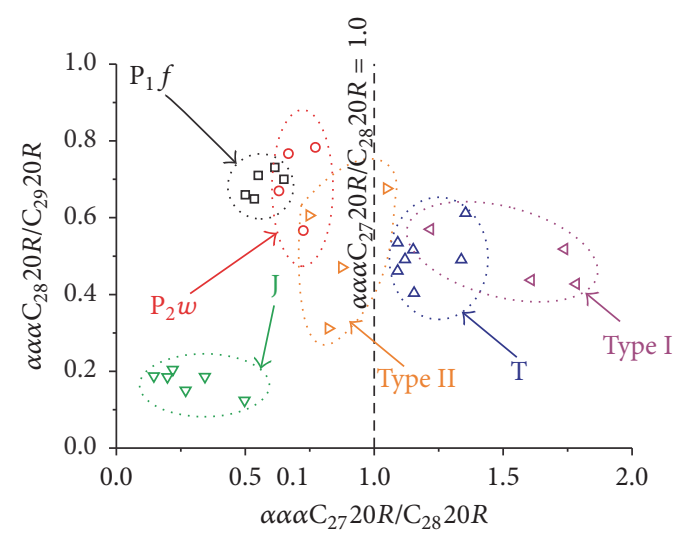

$\begin{array}{ll}\nabla \mathrm{J} \text { mudstone source rock } & \square \mathrm{P}_{1} f \text { mudstone source rock } \\ \Delta \mathrm{T} \text { mudstone source rock } & \triangleleft \text { Type A hydrocarbon } \\ \circ \mathrm{P}_{2} w \text { mudstone source rock } & \triangleright \text { Type } \mathrm{B} \text { hydrocarbon }\end{array}$

(f)

FIgure 5: Correlation of key biomarkers that distinguish the Permian, Jurassic, and Triassic mudstone source rocks and Triassic oil-source correlation in the central Junggar Basin. (a) $\mathrm{Pr} / n-\mathrm{C}_{17}$ versus $\mathrm{Ph} / n-\mathrm{C}_{18}$; (b) $\mathrm{Pr} / \mathrm{Ph}$ versus $\beta$-carotane $/ n$-alkane main peak; (c) $\mathrm{C}_{20} / \mathrm{C}_{21}$ TT versus $\mathrm{C}_{21} / \mathrm{C}_{23} \mathrm{TT}$; (d) regular sterane $\alpha \alpha \alpha \mathrm{C}_{27} 20 R / \mathrm{C}_{28} 20 R$ versus $\alpha \alpha \alpha \mathrm{C}_{28} 20 R / \mathrm{C}_{29} 20 R$; (e) Ts/Tm versus gammacerane/C $\mathrm{C}_{30}$ hopane; (f) TT main peak/PT main peak versus $\mathrm{C}_{24} \mathrm{TeT} / \mathrm{C}_{26} \mathrm{TT}$. TT: tricyclic terpane. TeT: tetracyclic terpane. PT: pentacyclic terpane. 


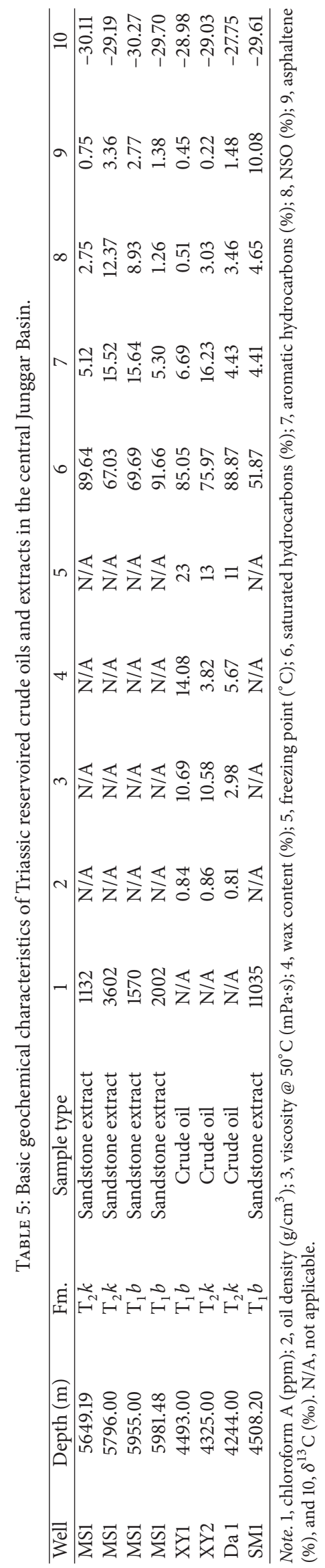


MS 1 well, $5955 \mathrm{~m}, \mathrm{~T}_{1} b$, sandstone extract,

Chloroform bitumen content $=1570 \mathrm{ppm}$,

Saturate hydrocarbons $=69.69 \%$, aromatic hydrocarbons $=15.64 \%$, NSO $=8.93 \%$, asphaltene $=2.77 \%$,

$\delta^{13} \mathrm{C}=-30.11 \%, \mathrm{Pr} / \mathrm{Ph}=0.88$,

$\mathrm{C}_{29}-20 S /(20 S+20 R)=0.44, \mathrm{C}_{29}-\beta \beta /(\alpha \alpha+\beta \beta)=0.54$.

GC

$m / z=191$

$m / z=217$
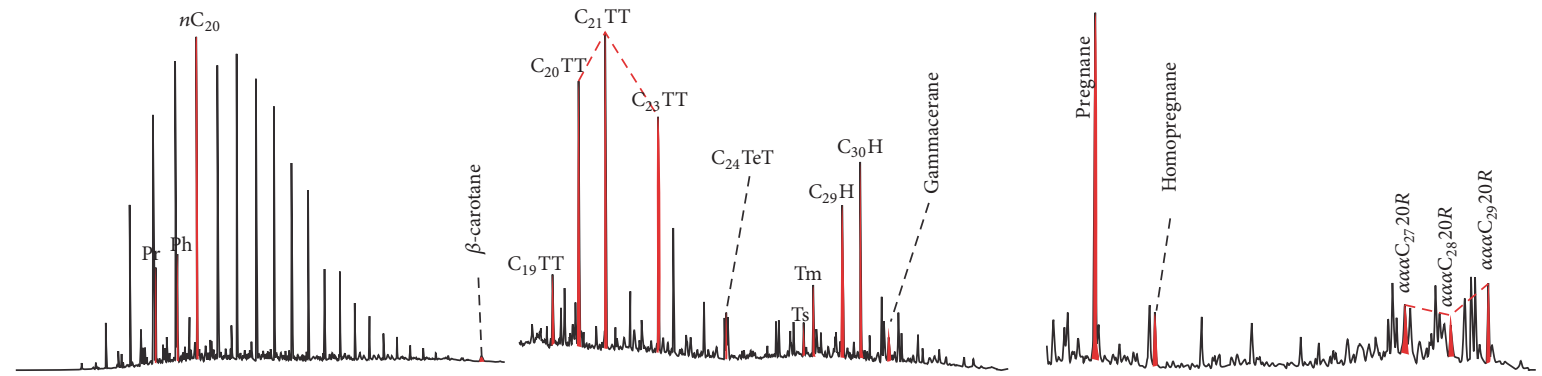

(a)

Da 1 well, $4244 \mathrm{~m}, \mathrm{~T}_{2} k$, crude oil,

Density $=0.81 \mathrm{~g} / \mathrm{cm}^{3}$,

Saturate hydrocarbons $=88.87 \%$, aromatic hydrocarbons $=4.43 \%, \mathrm{NSO}=3.46 \%$, asphaltene $=1.48 \%$,

$\delta^{13} \mathrm{C}=-27.75 \%, \mathrm{Pr} / \mathrm{Ph}=1.11$,

$\mathrm{C}_{29}-20 S /(20 S+20 R)=0.44, \mathrm{C}_{29}-\beta \beta /(\alpha \alpha+\beta \beta)=0.67$.

GC

$m / z=191$
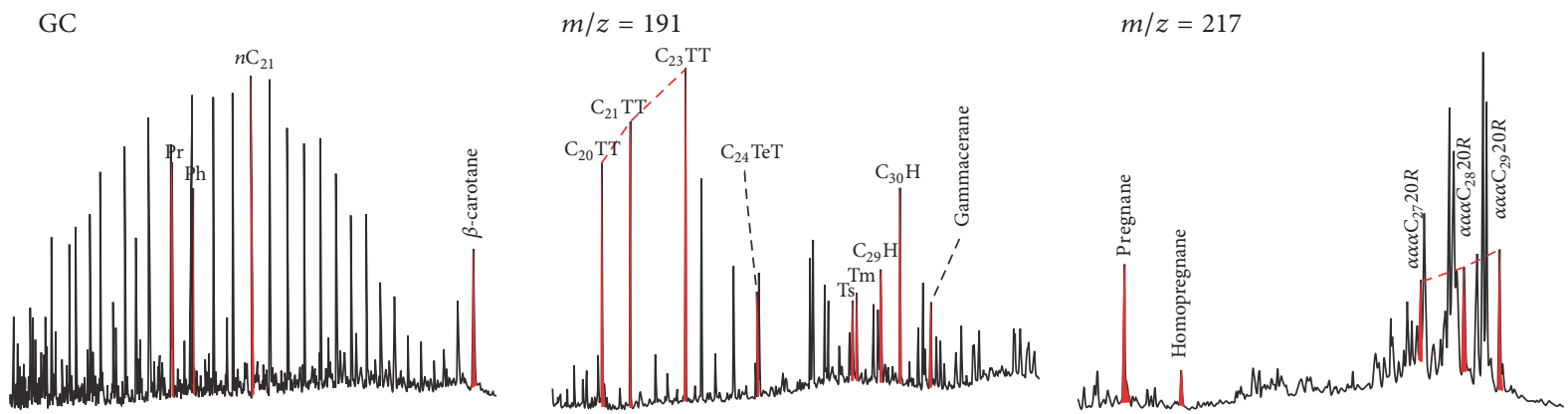

(b)

FIGURE 6: Gas and mass chromatograms of Triassic-reservoired oils and reservoir extracts in the central Junggar Basin. (a) The end-member type A. (b) The end-member type B. See text for the classification of these two types.

In this study, the maturity of oils and reservoir extracts only has a slight variation according to the two sterane parameters, that is, $C_{29} 20 S /(20 S+20 R)$ and Sterane $C_{29} \beta \beta /(\alpha \alpha+\beta \beta)$ (Table 3). Secondary alterations of oil (e.g., water washing, biodegradation, and oxidation) are weak (Figure 6). Thus, these two effects cannot influence the determination of oil classification and oil-source correlation.

The type A oils in this study can be exemplified by the sandstone extracts from well MS 1 . These samples have relatively low $\mathrm{Pr} / n-\mathrm{C}_{17}$ and $\mathrm{Ph} / n-\mathrm{C}_{18}$ ratios, which are in the ranges of $0.38-0.44$ and $0.33-0.53$, respectively. They have low $\beta$-carotane contents, as the ratio of $\beta$-carotane $/ n$-alkane main peak ranges between 0.06 and 0.19 . The distribution patterns of $\mathrm{C}_{20}, \mathrm{C}_{21}$, and $\mathrm{C}_{23}$ TT all follow the order of $\left.\mathrm{C}_{20}<\mathrm{C}_{21}\right\rangle$ $\mathrm{C}_{23}$ with the $\mathrm{C}_{23}$ abundance mostly being higher than that of the $\mathrm{C}_{20}$ TT. Relatively high concentrations of $\mathrm{C}_{24} \mathrm{TeT}$ were observed, such that all the samples have $\mathrm{C}_{24} \mathrm{TeT} / \mathrm{C}_{26} \mathrm{TT}$ ratios greater than 0.3. The $\mathrm{Ts} / \mathrm{Tm}$ ratios of these samples are 1.0-3.0. The concentrations of gammacerane are low in these samples, as evidenced by the ratio of gammacerane to $\mathrm{C}_{30}$ hopane being less than 0.2. The regular steranes are dominated by $\mathrm{C}_{29}$ and the $\mathrm{C}_{27}>\mathrm{C}_{28}$ regular steranes.

The type $\mathrm{B}$ oils in this study consist of the crude oils from the Da 1, XY 1, and XY 2 wells and one sandstone extract from well SM 1. These oils and extracts have biomarker characteristics remarkably different from those of type A. They have relatively high $\mathrm{Pr} / n-\mathrm{C}_{17}$ and $\mathrm{Ph} / n-\mathrm{C}_{18}$ ratios, which are in the ranges of $0.91-1.11$ and $0.62-0.96$, respectively. These samples have very high concentrations of $\beta$-carotane, as demonstrated by ratios of $\beta$-carotane $/ n$-alkane main peak between 0.47 and 0.97. The distribution patterns of $\mathrm{C}_{20}, \mathrm{C}_{21}$, and $\mathrm{C}_{23} \mathrm{TT}$ all follow the order of $\mathrm{C}_{20}<\mathrm{C}_{21}<\mathrm{C}_{23}$. The $\mathrm{C}_{24}$ TeT content is significantly low as the $\mathrm{C}_{24} \mathrm{TeT} / \mathrm{C}_{26} \mathrm{TT}$ ratios are all less than 0.2 . The samples have abundant gammacerane, as evidenced by the ratios of gammacerane to $\mathrm{C}_{30}$ hopane in the range of $0.28-0.52$. The regular steranes are dominated by $\mathrm{C}_{29}$ (40-60\%) and the concentration of the $\mathrm{C}_{27}$ regular sterane is generally close to that of $\mathrm{C}_{28}$. 


\subsection{Oil-Source Correlation}

4.4.1. Insights from Stable Carbon Isotopes. The bulk $\delta^{13} \mathrm{C}$ of the type A and type B Triassic-reservoired crude oils and reservoir extracts is similar which varies within $-30.27 \sim-29.70 \%$ o and $-29.61 \sim-27.75 \%$, respectively. These values are generally consistent with the Triassic mudstone source rocks, whose bulk $\delta^{13} \mathrm{C}$ ranges between $-30.46 \%$ and $-26.30 \%$ and different to Jurassic and Permian source rocks, whose bulk $\delta^{13} \mathrm{C}$ values are generally $>-28 \%$ and $<-30 \%$, respectively. This might suggest that Triassic mudstone source rocks have contributions to the Triassic-reservoired hydrocarbons.

4.4.2. Insights from Biomarkers. To perform the oil-source correlation, we use some indicative biomarker ratios (Figure 5). Results show that the type A oils and extracts have similar $\mathrm{Pr} / n-\mathrm{C}_{17}$ and $\mathrm{Ph} / n-\mathrm{C}_{18}$ ratios to $\mathrm{P}_{2} w$ sourced hydrocarbons and Triassic source rocks (Figure 5(a)). In contrast, the type $\mathrm{B}$ oils and extracts are very close to those of the $\mathrm{P}_{1} f$ sourced hydrocarbons (Figure 5(a)).

An examination of $\beta$-carotane (Figure $5(\mathrm{~b})$ ) indicates that the type $A$ oils and extracts are similar to $\mathrm{P}_{2} w$ sourced hydrocarbons, as the ratios of $\beta$-carotane $/ n$-alkane main peak are all less than 0.2 . In contrast, the type B oils and extracts exhibit the ratios similar to $\mathrm{P}_{1} f$ sourced hydrocarbons, with the values of $\beta$-carotane $/ n$-alkane main peak all greater than 0.4 . The Triassic source rocks have values of $\beta$-carotane $/ n$ alkane main peak generally between type A and type B oils and extracts.

In terms of the distribution pattern of $\mathrm{C}_{20}, \mathrm{C}_{21}$, and $\mathrm{C}_{23} \mathrm{TT}$ (Figure 5(c)), the type A oils and extracts are similar to $\mathrm{P}_{2} \mathrm{w}$ sourced hydrocarbons in the order of $\mathrm{C}_{20}<\mathrm{C}_{21}>\mathrm{C}_{23}$. The type $\mathrm{B}$ oils and extracts are similar to $\mathrm{P}_{1} f$ sourced hydrocarbons, as the pattern of $\mathrm{C}_{20}<\mathrm{C}_{21}<\mathrm{C}_{23}$ is dominant. In contrast, the Triassic source rocks exhibit diverse distribution patterns of $\mathrm{C}_{20}, \mathrm{C}_{21}$, and $\mathrm{C}_{23} \mathrm{TT}$, with $\mathrm{C}_{20}>\mathrm{C}_{21}>\mathrm{C}_{23}$ in dominance.

Figure 5(d) shows that both the type A and type B oils and extracts have the ratio of the TT main peak/PT main peak (0.74-5.74) significantly higher than those of the Triassic and Jurassic source rocks. As this ratio is not only controlled by the hydrocarbon source but also influenced by hydrocarbon maturity $[3,51]$, the high value $>1.0$ might also be influenced by higher levels of maturity of the oils and extracts [46]. AS indicated in Figure 5(d), the high Ts/Tm ratios correlate well with the highly mature Permian oil $[48,52]$.

Figure 5(e) shows that the Ts/Tm ratios of the two types of oils and extracts are significantly higher than those of the Triassic and Jurassic-sourced rocks. Similar to the relative abundance of TT/PT, the Ts/Tm ratio is also influenced by both organic facies and maturity of the organic matter [46]. As such, such high Ts/Tm ratios could also be caused by high maturity of the Triassic-reservoired hydrocarbons, similar to the TT/PT ratio as discussed above. Shown by Figure 5(e), the high Ts/Tm ratios correlate well with the highly mature Permian oil $[48,52]$.

Regarding the gammacerane concentration (Figure 5(e)), the type $A$ oils and extracts are similar to the $\mathrm{P}_{2} w$ sourced hydrocarbons and Triassic mudstone source rocks in their low content, as the ratios of gammacerane $/ \mathrm{C}_{30}$ hopane are all less than 0.2. In contrast, type $\mathrm{B}$ oils and extracts exhibit the ratios of gammacerane $/ \mathrm{C}_{30}$ hopane greater than 0.2 , similar to those of the $\mathrm{P}_{1} f$ source hydrocarbons.

Figure 5(f) reveals that each type of oils and extracts has samples with regular sterane compositions of either $\mathrm{C}_{27}<\mathrm{C}_{28}$ or $\mathrm{C}_{27}>\mathrm{C}_{28}$. As discussed above, the Permian and Jurassicsourced hydrocarbons are generally characterized by $\mathrm{C}_{27}<$ $\mathrm{C}_{28}$, whereas the $\mathrm{C}_{27}>\mathrm{C}_{28}$ pattern is found only in Triassic source rocks in the study area. This suggests that the Triassic oils and extracts are likely influenced by the contribution of Triassic-generated oils, especially for the type A samples.

Based on the above results and discussion, it appears that both the two types of oils and extracts are derived little from the Jurassic source rocks in terms of either carbon isotopes or biomarker compositions. In contrast, there are many overlaps in carbon isotopes and biomarker compositions between the Triassic-reservoired hydrocarbons and the Permian and Triassic source rocks. Thus, we interpret the Triassic-reservoired crude oils and reservoir extracts as a mix of Permian and Triassic source rocks. The contribution from the Triassic source rocks is particularly exemplified by the distribution pattern of regular steranes $\mathrm{C}_{27}, \mathrm{C}_{28}$, and $\mathrm{C}_{29}$. This pattern is characterized by $\mathrm{C}_{27}<\mathrm{C}_{28}<\mathrm{C}_{29}$ for both $\mathrm{P}_{1} f$ - and $\mathrm{P}_{2} w$ sourced hydrocarbons $[48,53,54]$. However, Triassic-sourced hydrocarbons have distinctive pattern of $\mathrm{C}_{27}>\mathrm{C}_{28}<\mathrm{C}_{29}$ which is also observed in the eastern Junggar Basin $[14,15]$. This strongly implies that the Triassic-reservoired oils and extracts in the central Junggar Basin have some contributions from Triassic source rocks, especially those having regular steranes $\mathrm{C}_{27}>\mathrm{C}_{28}$.

4.4.3. Rough Evaluation of Oil-Source Contributions. To quantitatively constrain the contribution from Triassic source rocks to Triassic-reservoired hydrocarbons, a mathematical calculation method was employed, although it is rather difficult to determine the relative contribution to mixed oils of three or more source rocks $[3,14,15]$. We estimate the proportional contributions by using the end-member oils from the different source rocks. In theory, representative end-member Permian- and Triassic-sourced oils that have similar maturity with the Triassic-reservoired hydrocarbons should be used. However, the Permian-sourced end-member oils used in this study may have different maturities to the Triassic-reservoired crude oils and extracts shown by the higher values of Ts/Tm and TTs/PTs of the Triassic-reservoired crude oils and extracts. Thus, only the biomarker ratios independent of maturity were selected for the calculation. As such, the parameters used in this study include $\delta^{13} \mathrm{C}, \mathrm{C}_{24} \mathrm{TeT} /$ $\mathrm{C}_{26} \mathrm{TT}, \mathrm{Pr} / \mathrm{Ph}, \mathrm{C}_{27} / \mathrm{C}_{28}$ regular sterane, and gammacerane/ $\mathrm{C}_{30}$ hopane.

However, due to complex mixing mechanism and possible alteration during and after mixing, the relationship between sources and mixed oils might be nonlinear and the calculation of mixing proportion based on biomarker ratios may lead to incorrect results. Under these circumstances, average values of biomarker ratios were used. Therefore, average values of the $\mathrm{P}_{2} w$ - and $\mathrm{P}_{1} f$-sourced oils are used 
TABLE 6: Representative parameters and their values used in calculation of oil-source contribution.

\begin{tabular}{|c|c|c|c|c|c|c|}
\hline Well/Fm. & Source & $\delta^{13} \mathrm{C}$ & $\mathrm{Pr} / \mathrm{Ph}$ & $\mathrm{C}_{24} \mathrm{TeT} / \mathrm{C}_{26} \mathrm{TT}$ & $\mathrm{C}_{27} / \mathrm{C}_{28}$ sterane & Gammacerane/ $\mathrm{C}_{30}$ hopane \\
\hline $\mathrm{M} 101 / \mathrm{J}_{1} s$ & $\mathrm{P}_{2} w$ & -28.82 & 1.48 & 0.44 & 0.72 & 0.10 \\
\hline $\mathrm{M} 106 / \mathrm{J}_{1} s$ & $\mathrm{P}_{2} w$ & -28.81 & 1.57 & 0.42 & 0.63 & 0.15 \\
\hline $\mathrm{SN} 31 / \mathrm{K}_{1} \mathrm{tg}$ & $\mathrm{P}_{2} w$ & -28.34 & 1.80 & 0.39 & 0.67 & 0.10 \\
\hline $\mathrm{S} 015 / \mathrm{J}_{1} s$ & $\mathrm{P}_{2} w$ & -29.15 & 1.52 & 0.37 & 0.77 & 0.11 \\
\hline $\mathrm{S} 022 / \mathrm{J}_{1} b$ & $\mathrm{P}_{2} w$ & -29.36 & 1.40 & 0.36 & 0.75 & 0.14 \\
\hline $\mathrm{S} 001 / \mathrm{J}_{1} b$ & $\mathrm{P}_{1} f$ & -30.83 & 0.85 & 0.15 & 0.61 & 0.32 \\
\hline $\mathrm{S} 022 / \mathrm{J}_{1} b$ & $\mathrm{P}_{1} f$ & -30.64 & 0.91 & 0.17 & 0.54 & 0.36 \\
\hline $\mathrm{SX} 1 / \mathrm{J}_{1} b$ & $\mathrm{P}_{1} f$ & -30.60 & 0.88 & 0.20 & 0.50 & 0.42 \\
\hline $\mathrm{Lu} 9 / \mathrm{K}_{1} \mathrm{tg}$ & $\mathrm{P}_{1} f$ & -30.44 & 0.75 & 0.23 & 0.65 & 0.40 \\
\hline $\mathrm{Lu} 12 / \mathrm{K}_{1} \operatorname{tg}$ & $\mathrm{P}_{1} f$ & -30.39 & 0.82 & 0.19 & 0.55 & 0.35 \\
\hline N/A & $\mathrm{P}_{2} w^{*}$ & -28.90 & 1.55 & 0.40 & 0.71 & 0.12 \\
\hline N/A & $\mathrm{P}_{1} f^{*}$ & -30.58 & 0.84 & 0.19 & 0.57 & 0.37 \\
\hline N/A & Triassic ${ }^{*}$ & -28.57 & 1.19 & 0.65 & 1.20 & 0.12 \\
\hline
\end{tabular}

Note. ${ }^{*}$ Average value of the source, that is, value used to represent each group. N/A, not applicable.

as representative values of Permian-sourced hydrocarbons. Average values of the Triassic mudstone extracts are used to represent values of Triassic-sourced hydrocarbons. Average values of the type $A$ and type $B$ crude oils and extracts are used as representative features of mixed oils to calculate proportions of different sources to the type A and type B hydrocarbons, respectively. The values are listed in Table 6. Secondly, for the three-sourced mixed oil, the following equations can be used to estimate the contribution of each input:

$$
\begin{aligned}
f_{1}+f_{2}+f_{3} & =1, \\
X_{11} f_{1}+X_{12} f_{2}+X_{13} f_{3} & =Y_{1}, \\
X_{21} f_{1}+X_{22} f_{2}+X_{23} f_{3} & =Y_{2}, \\
& \quad 0<f_{1}, f_{2}, f_{3}<1,
\end{aligned}
$$

where $X_{i j}$ refers to biomarker ratio of each source, $Y_{i}$ refers to the biomarker ratio of mixed oils and $f_{i}$ refers to the proportion of each source. Based on those constrained mathematical conditions above, linear regression shows that contributions of Triassic source rocks to the type A and type B hydrocarbons are $67 \%$ and $31 \%$, respectively. The contributions of $\mathrm{P}_{2} w$ source rocks to the type A and type B hydrocarbons are $22 \%$ and $5 \%$, respectively. The contributions of $\mathrm{P}_{1} f$ source rocks to the type A and type B hydrocarbons are $11 \%$ and $64 \%$, respectively. Thus, the mixing calculation results show that both the type A and type B hydrocarbons have contributions from Triassic source rocks to varying degrees.

4.5. Implications for Oil-Generation Potential of the Triassic Lacustrine Mudstone. As outlined above, the critical issue for the hydrocarbon potential of Triassic mudstones in the Junggar Basin is its oil generation. The discovered oil accumulations in the study area to date are mainly Permian-sourced. However, our study suggests that the two types of Triassicreservoired oils and extracts cannot be fully excluded from the infiltration of Triassic-generated oils. Thus, the Triassic mudstones in the Junggar Basin might have oil-generation potential, although the contribution from these Triassicgenerated oils may be relatively small. This suggests that the Triassic mudstones are likely a set of important oil-source rocks that have been overlooked in previous exploration and studies. Triassic-sourced hydrocarbons might be accumulated in depressions which are poorly explored, as mudstones in these areas have organic matter of higher organic abundance and better organic matter type relative to those in uplifts $[55,56]$.

However, note that both the two types of Triassic-reservoired hydrocarbons in this study are similar to the Permiansourced oils in terms of overall geochemical characteristics. Thus, the subsequent studies should focus on elucidating the Triassic evolution of hydrocarbon generation and accumulation and on more reliably quantifying the contribution from the Triassic-generated oils, thereby providing more accurate information for exploration.

In summary, the Triassic lacustrine mudstones in the Junggar Basin could be another set of effective source rocks and thus a new Triassic petroleum system might exist.

\section{Conclusions}

(1) The deep-buried Triassic lacustrine mudstone source rocks in the central Junggar Basin have distinctive bulk carbon isotopes and biomarker compositions that are distinguishable from the generally accepted Permian and Jurassic source rocks. The average $\delta^{13} \mathrm{C}$ values of the kerogen and extracts from the Triassic mudstones are $-26.77 \%$ o and $-28.57 \%$, respectively. In terms of biomarkers, these mudstones have $\mathrm{Pr} / \mathrm{Ph}$ of approximately $1.2, \mathrm{C}_{24} \mathrm{TeT} / \mathrm{C}_{26} \mathrm{TT}$ around 0.65 , and gammacerane $/ \mathrm{C}_{30}$ hopane averaging at 0.12 . In addition, the rocks contain more $\mathrm{C}_{27}$ than $\mathrm{C}_{28}$ regular steranes.

(2) The deep-buried Triassic-reservoired oils and extracts in the central Junggar Basin can be geochemically divided into two types. Both of these two types, especially type A, have oil contribution from the Triassic mudstones. The 
proportions for type A and type B hydrocarbons are $67 \%$ and $31 \%$, respectively. This implies the oil-generation potential of the Triassic lacustrine mudstones in the central Junggar Basin.

(3) Given the wide distribution of the Triassic mudstones throughout the Junggar Basin and favorable geochemical features, the deep-buried Triassic lacustrine mudstones are likely another set of important hydrocarbon source rocks in the basin. As such, the Triassic mudstones deserve more attention and require further study to elucidate their hydrocarbon potential and an evaluation of the Triassic petroleum system is required.

\section{Conflicts of Interest}

The authors declare that they have no conflicts of interest.

\section{Acknowledgments}

The authors thank Professors Xiaorong Luo and Shuichang Zhang for their encouragement to complete the manuscript. This work was jointly funded by National Science and Technology Major Project of China (Grant no. 2016ZX05001005) and National Natural Science Foundation of China (Grant nos. 41322017 and 41472100).

\section{References}

[1] H. R. Grunau, "Abundance of source rocks for oil and gas worldwide.," Journal of Petroleum Geology, vol. 6, pp. 39-54, 1983.

[2] H. D. Klemme and G. F. Ulmishek, "Effective petroleum source rocks of the world: stratigraphic distribution and controlling depositional factors," AAPG Bulletin, vol. 75, no. 12, pp. 1809$1851,1991$.

[3] K. E. Peters, C. C. Walters, and J. M. Moldowan, The Biomarker Guide: Interpreting Molecular Fossils in Petroleum and Ancient Sediments, Cambridge University Press, UK, second edition, 2005.

[4] A. D. Hanson, B. D. Ritts, and J. M. Moldowan, "Organic geochemistry of oil and source rock strata of the Ordos Basin northcentral China," AAPG Bulletin, vol. 91, no. 9, pp. 1273-1293, 2007.

[5] D. Liang, S. Zhang, J. Chen, F. Wang, and P. Wang, "Organic geochemistry of oil and gas in the Kuqa depression, Tarim Basin, NW China," Organic Geochemistry, vol. 34, no. 7, pp. 873888, 2003.

[6] W. Ding, H. Wan, A. Su, and Z. He, "Characteristics of Triassic marine source rocks and prediction of favorable source kitchens in Qiangtang Basin, Tibet," Energy Exploration and Exploitation, vol. 29, no. 2, pp. 143-160, 2011.

[7] G. Ulmishek, "Geology and petroleum resources of basins," Argonne National Laboratory ANL/ES-146, p. 131, 1984.

[8] A. R. Carroll, L. Yunhai, S. A. Graham et al., "Junggar basin, northwest China: trapped Late Paleozoic ocean," Tectonophysics, vol. 181, no. 1-4, pp. 1-14, 1990.

[9] S. A. Graham, S. Brassell, A. R. Carroll et al., "Characteristics of selected petroleum source rocks, Xinjiang Uygur Autonomous Region, Northwest China," AAPG Bulletin, vol. 74, pp. 493-512, 1990.
[10] A. R. Carroll, S. C. Brasssel, and S. A. Graham, "Upper Permian lacustrine oil shales, southern Junggar Basin, northwest China," AAPG Bulletin, vol. 76, pp. 1874-1902, 1992.

[11] M. S. Hendrix, S. C. Brassell, A. R. Carroll, and S. A. Graham, "Sedimentology, organic geochemistry, and petroleum potential of Jurassic Coal Measures: Tarim, Junggar, and Turpan Basins, Northwest China," AAPG Bulletin, vol. 79, pp. 929-958, 1995.

[12] J. L. Clayton, J. Yang, J. D. King, P. G. Lillis, and A. Warden, "Geochemistry of oils from the Junggar basin, northwest China," AAPG Bulletin, vol. 81, pp. 1926-1944, 1997.

[13] Z. Jin, J. Cao, W. Hu et al., "Episodic petroleum fluid migration in fault zones of the northwestern Junggar Basin (nortwest China): Evidence from hydrocarbon-bearing zoned calcite cement," AAPG Bulletin, vol. 92, no. 9, pp. 1225-1243, 2008.

[14] J. Chen, D. Liang, X. Wang et al., "Mixed oils derived from multiple source rocks in the Cainan oilfield, Junggar Basin, Northwest China. Part I: Genetic potential of source rocks, features of biomarkers and oil sources of typical crude oils," Organic Geochemistry, vol. 34, no. 7, pp. 889-909, 2003.

[15] J. Chen, C. Deng, D. Liang et al., "Mixed oils derived from multiple source rocks in the Cainan oilfield, Junggar Basin, Northwest China. Part II: Artificial mixing experiments on typical crude oils and quantitative oil-source correlation," Organic Geochemistry, vol. 34, no. 7, pp. 911-930, 2003.

[16] M. Wu, J. Cao, X. Wang et al., "Hydrocarbon generation potential of Triassic mudstones in the Junggar Basin, northwest China," AAPG Bulletin, vol. 98, no. 9, pp. 1885-1906, 2014.

[17] G. Dam and F. G. Christiansen, "Organic geochemistry and source potential of the lacustrine shales of the Upper Triassic Lower Jurassic Kap Stewart Formation, East Greenland," Marine and Petroleum Geology, vol. 7, no. 4, pp. 428-443, 1990.

[18] L. B. Clemmensen, D. V. Kent, and F. A. Jenkins Jr., "A Late Triassic lake system in East Greenland: Facies, depositional cycles and palaeoclimate," Palaeogeography, Palaeoclimatology, Palaeoecology, vol. 140, no. 1-4, pp. 135-159, 1998.

[19] Z. H. Zhang, Y. Y. Wu, K. Yu et al., "Geochemical characteristics of source rocks in Changling area, Songliao Basin," Xinjiang Petroleum Geology, vol. 23, pp. 501-506, 2002 (Chinese).

[20] Z. H. Feng, W. Fang, Z. G. Li et al., "Depositional environment of terrestrial petroleum source rocks and geochemical indicators in the Songliao Basin," Science China Earth Sciences, vol. 54, no. 9, pp. 1304-1317, 2011.

[21] S. S. Luo, Z. Z. Gao, and X. W. Yang, "Sedimentary system in Baixiantan formation of Baikouquan oilfield in Xinjiang," Journal of Oil and Gas Technology, vol. 28, pp. 15-17, 2006 (Chinese).

[22] B. L. Liu, Q. F. Wang, and S. M. Yan, "Triassic stratigraphic and sedimentary characteristics of Well Z2 from central Junggar Basin, Xinjiang," Journal of Stratigraphy, vol. 32, pp. 188-193, 2008 (Chinese).

[23] B. Z. Xian, H. B. Xu, Z. K. Jin et al., "Sequence stratigraphy and subtle reservoir exploration of Triassic system in northwestern margin of Junggar Basin," Geological Journal of China Universities, vol. 14, pp. 139-146, 2008 (Chinese).

[24] D. F. He, X. F. Chen, Y. J. Zhang et al., "Enrichment characteristics of oil and gas in Junggar Basin," Acta Petrolei Sinica, vol. 25, pp. 1-10, 2004 (Chinese).

[25] J. Cao, Y. Zhang, W. Hu et al., “The Permian hybrid petroleum system in the northwest margin of the Junggar Basin, northwest China," Marine and Petroleum Geology, vol. 22, no. 3, pp. 331349, 2005. 
[26] Y. Q. Zhang and N. F. Zhang, "Oil/gas enrichment of large superimposed basin in Junggar Basin," China Petroleum Exploration, vol. 11, pp. 59-65, 2006 (Chinese).

[27] A. R. Carroll, "Upper Permian lacustrine organic facies evolution, Southern Junggar Basin, NW China," Organic Geochemistry, vol. 28, no. 11, pp. 649-667, 1998.

[28] M. J. Zhang and P. Yang, "The characteristics and analysis of reservoir-forming conditions of the Carboniferous oil and gas pools in Junggar Basin," Journal of Xinjiang Petroleum Institute, vol. 2, pp. 8-13, 2000 (Chinese).

[29] G. L. Tao, W. X. Hu, J. Cao et al., "Exploration prospect of Jurassic source derived oils in the Central Junggar Basin, NW China," Geological Review, vol. 54, pp. 478-484, 2008 (Chinese).

[30] J. Cao, X. Wang, P. Sun et al., "Geochemistry and origins of natural gases in the central Junggar Basin, northwest China," Organic Geochemistry, vol. 53, pp. 166-176, 2012.

[31] E. S. Scalan and J. E. Smith, "An improved measure of the oddeven predominance in the normal alkanes of sediment extracts and petroleum," Geochimica et Cosmochimica Acta, vol. 34, no. 5, pp. 611-620, 1970.

[32] G. R. Wang, "Classification of tectonic units and geologic evolution in the northern Xinjiang and neighboring areas," Xinjiang Geology, vol. 14, pp. 12-27, 1996 (Chinese).

[33] J. Y. Li, G. Q. He, X. Xu et al., "Crustal tectonic framework of Northern Xinjiang and adjacent regions and its formation," Acta Sedimentologica Sinica, vol. 80, 2006 (Chinese).

[34] Z. R. Yang and H. M. Gu, "Preliminary results of aeromagnetic data: implication for property and evolution of basement of the Junggar Basin," Xinjiang Petroleum Geology, vol. 8, pp. 37-45, 1987 (Chinese).

[35] B. Zhao, "Nature of basement of Junggar Basin," Xinjiang Petroleum Geology, vol. 13, pp. 95-99, 1992 (Chinese).

[36] B. Lu, J. Zhang, T. Li, and M. A. Lu, "Analysis of tectonic framework in Junggar Basin," Xinjiang Petroleum Geology, vol. 29, pp. 284-289, 2008 (Chinese).

[37] F. Hao, X. Zhou, Y. Zhu, and Y. Yang, "Lacustrine source rock deposition in response to co-evolution of environments and organisms controlled by tectonic subsidence and climate, Bohai Bay Basin, China," Organic Geochemistry, vol. 42, no. 4, pp. 323339, 2011.

[38] D. F. Huang, J. C. Li, and D. J. Zhang, "Kerogen types and study on effectiveness, limitation and interrelation of their identification parameters," Acta Sedimentologica Sinica, vol. 2, pp. 18-33, 1984 (Chinese).

[39] J. Hunt, Petroleum geochemistry and geology, W. H. Freeman and Co., New York, NY, USa, 1995.

[40] K. E. Peters and J. M. Moldowan, "Effects of source, thermal maturity, and biodegradation on the distribution and isomerization of homohopanes in petroleum," Organic Geochemistry, vol. 17, no. 1, pp. 47-61, 1991.

[41] J. K. Volkman, M. R. Banks, K. Denwer, and F. R. Aquino Neto, "Biomarker composition and depositional settings of Tasmanite oil shale from northern Tasmania, Australia," in Proceedings of the 14th International Meeting on Organic Geochemistry, Paris, September 18-22, 1989.

[42] J. Cao, S. Yao, Z. Jin et al., "Petroleum migration and mixing in the northwestern Junggar Basin (NW China): constraints from oil-bearing fluid inclusion analyses," Organic Geochemistry, vol. 37, no. 7, pp. 827-846, 2006.

[43] J. M. Moldowan, W. K. Seifert, and E. J. Gallegos, "Relationship between petroleum composition and depositional environment of petroleum source rocks," AAPG Bulletin, vol. 69, pp. 1255$1268,1985$.

[44] I. Rubinstein, O. Sieskind, and P. Albrecht, "Rearranged sterenes in a shale: occurrence and simulated formation," Journal of the Chemical Society: Perkin Transactions, vol. 1, no. 19, pp. 18331836, 1975.

[45] O. Sieskind, G. Joly, and P. Albrecht, "Simulation of the geochemical transformations of sterols: superacid effect of clay minerals," Geochimica et Cosmochimica Acta, vol. 43, no. 10, pp. 1675-1679, 1979.

[46] J. M. Moldowan, P. Sundararaman, and M. Schoell, "Sensitivity of biomarker properties to depositional environment and/or source input in the Lower Toarcian of SW-Germany," Organic Geochemistry, vol. 10, no. 4-6, pp. 915-926, 1986.

[47] D. Brincat and G. Abbott, "Some aspects of the molecular biogeochemistry of laminated of massive rocks from the Naples Beach Section (Santa Barbara-Ventura Basin)," in The Monterey Formation: From Rocks to Molecules, C. M. Isaacs and J, J. Rulkötter, and eds, Eds., pp. 140-149, Columbia University Press, New York, NY, USA, 2001.

[48] X. L. Wang, Research on hydrocarbon source and accumulation of Penljingxi depression, Junggar Basin. Nanchong, Sichuan [Ph.D. thesis], Southwest Petroleum University, Chengdu, China, 2001.

[49] S. Larter, A. Wilhelms, I. Head et al., "The controls on the composition of biodegraded oils in the deep subsurface - Part 1: Biodegradation rates in petroleum reservoirs," Organic Geochemistry, vol. 34, no. 4, pp. 601-613, 2003.

[50] C. M. Aitken, D. M. Jones, and S. R. Larter, "Anaerobic hydrocarbon biodegradation in deep subsurface oil reservoirs," Nature, vol. 431, no. 7006, pp. 291-294, 2004.

[51] W. K. Seifert and J. Michael Moldowan, "Applications of steranes, terpanes and monoaromatics to the maturation, migration and source of crude oils," Geochimica et Cosmochimica Acta, vol. 42, no. 1, pp. 77-95, 1978.

[52] X. L. Wang and S. F. Kang, "Analysis of crude origin in hinterland and slope of northwestern margin, Junggar Basin," Xinjiang Petroleum Geology, vol. 20, pp. 109-112, 1999 (Chinese).

[53] X. B. Shi, X. L. Wang, J. Cao et al., "Genetic type of oils and their migration/accumulation in the Mobei-Mosuowan area, central Junggar Basin," Acta Sedmentologica Sinica, vol. 28, pp. 380-387, 2010, 2010 (Chinese).

[54] F. Hao, Z. Zhang, H. Zou, Y. Zhang, and Y. Yang, "Origin and mechanism of the formation of the low-oil-saturation Moxizhuang field, Junggar Basin, China: Implication for petroleum exploration in basins having complex histories," AAPG Bulletin, vol. 95, no. 6, pp. 983-1008, 2011.

[55] K. Kelts, "Environments of deposition of lacustrine petroleum source rocks: An introduction," Geological Society Special Publication, vol. 40, pp. 3-26, 1988.

[56] B. J. Katz, "Controlling factors on source rock development-a review of productivity, preservation and sedimentation rate," SEPM Special Publication, vol. 82, N.B. Harris edition, pp. 7-16, 2005. 

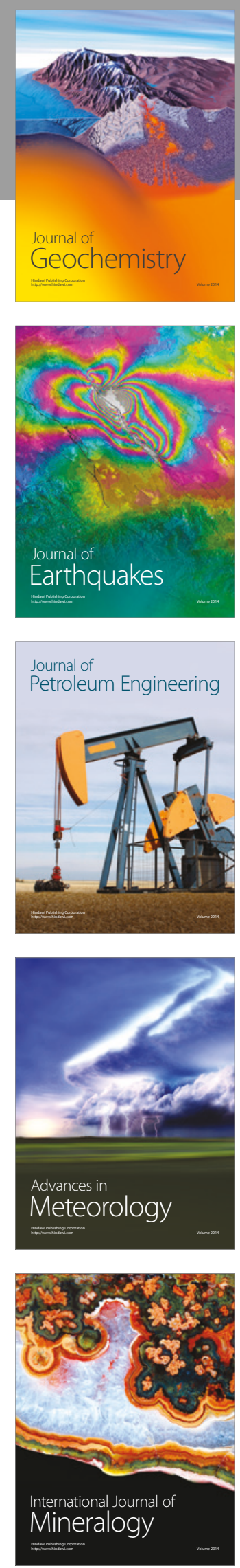
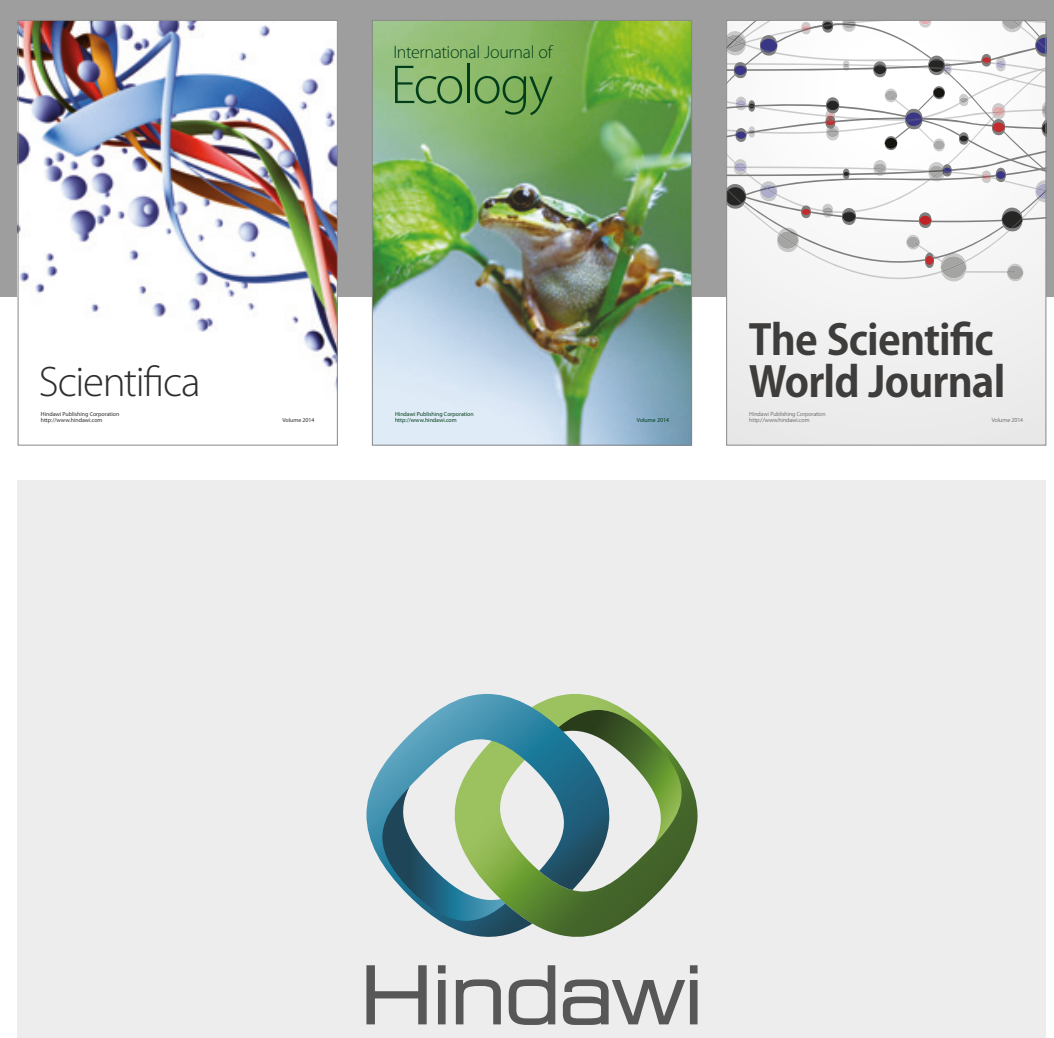

Submit your manuscripts at

https://www.hindawi.com
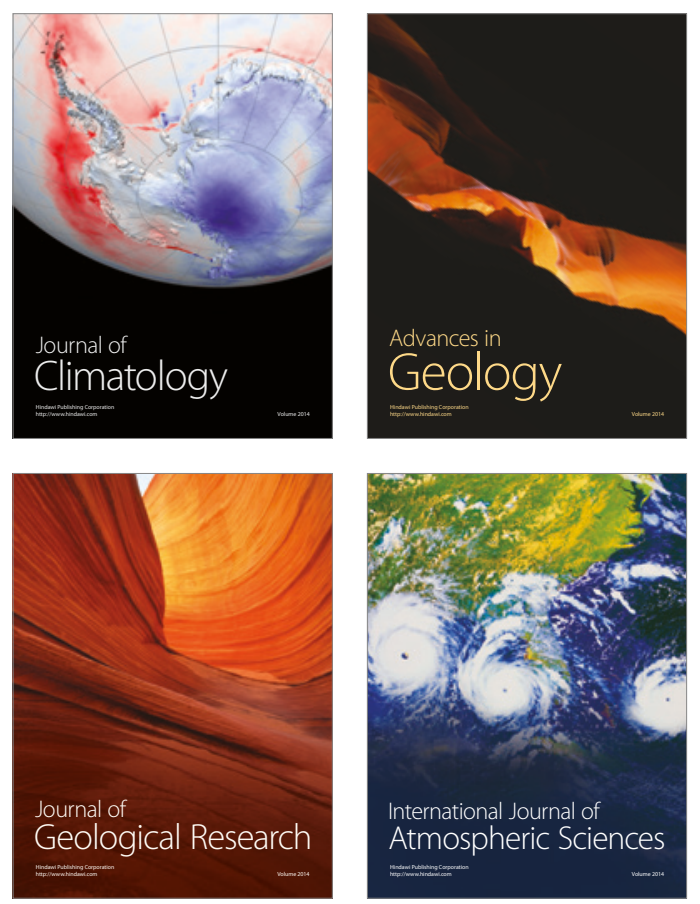

The Scientific

World Journal
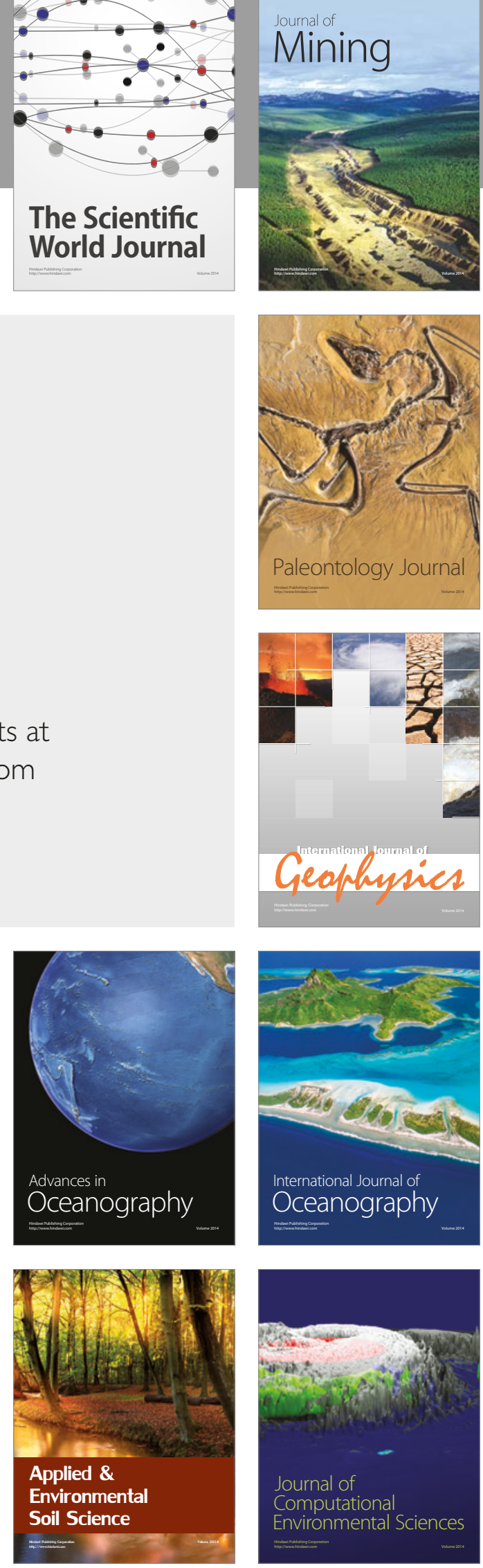